\title{
Quantitative Temporal in Vivo Proteomics Deciphers the Transition of Virus-Driven Myeloid Cells into M2 Macrophages
}

\section{Citation}

Clements, D., J. P. Murphy, A. Sterea, B. E. Kennedy, Y. Kim, E. Helson, S. Almasi, et al. 2017. "Quantitative Temporal in Vivo Proteomics Deciphers the Transition of Virus-Driven Myeloid Cells into M2 Macrophages." Journal of Proteome Research 16 (9): 3391-3406. doi:10.1021/ acs.jproteome.7b00425. http://dx.doi.org/10.1021/acs.jproteome.7b00425.

\section{Published Version}

doi:10.1021/acs.jproteome.7b00425

\section{Permanent link}

http://nrs.harvard.edu/urn-3:HUL.InstRepos:34492214

\section{Terms of Use}

This article was downloaded from Harvard University's DASH repository, and is made available under the terms and conditions applicable to Other Posted Material, as set forth at http:// nrs.harvard.edu/urn-3:HUL.InstRepos:dash.current.terms-of-use\#LAA

\section{Share Your Story}

The Harvard community has made this article openly available.

Please share how this access benefits you. Submit a story.

Accessibility 


\section{Quantitative Temporal in Vivo Proteomics Deciphers the Transition of Virus-Driven Myeloid Cells into M2 Macrophages}

Derek R. Clements, ${ }^{\dagger}$ John Patrick Murphy, ${ }^{\ddagger}$ Andra Sterea, ${ }^{\S}$ Barry E. Kennedy, ${ }^{\ddagger}$ Youra Kim, ${ }^{\dagger}$ Erin Helson, ${ }^{\ddagger}, \|$ Shekoufeh Almasi, ${ }^{\S}$ Namit Holay, ${ }^{\dagger}$ Prathyusha Konda, ${ }^{\ddagger}$ Joao A. Paulo, ${ }^{\perp}$ Tanveer Sharif, ${ }^{\ddagger}$ Patrick W. Lee, ${ }^{\dagger,+}$ Michael P. Weekes, ${ }^{\#}$ Steven P. Gygi, ${ }^{\perp}$ and Shashi Gujar ${ }^{*},+\neq, \$, \nabla_{\odot}$

Departments of ${ }^{\dagger}$ Pathology, ${ }^{\ddagger}$ Microbiology \& Immunology, and ${ }^{\S}$ Biology, Dalhousie University, Halifax, Nova Scotia B3H 1X5, Canada

"Faculty of Medicine, University of Toronto, Toronto, Ontario M5S 1A8, Canada

${ }^{\perp}$ Department of Cell Biology, Harvard Medical School, Boston, Massachusetts 02115, United States

${ }^{\#}$ Cambridge Institute for Medical Research, University of Cambridge, Cambridge CB2 0XY, United Kingdom

${ }^{\nabla}$ Centre for Innovative and Collaborative Health Systems Research, IWK Health Centre, Halifax, Nova Scotia B3K 6R8, Canada

Supporting Information

ABSTRACT: Myeloid cells play a central role in the context of viral eradication, yet precisely how these cells differentiate throughout the course of acute infections is poorly understood. In this study, we have developed a novel quantitative temporal in vivo proteomics (QTiPs) platform to capture proteomic signatures of temporally transitioning virus-driven myeloid cells directly in situ, thus taking into consideration host-virus interactions throughout the course of an infection. QTiPs, in combination with phenotypic, functional, and metabolic analyses, elucidated a pivotal role for inflammatory $\mathrm{CD} 11 \mathrm{~b}^{+}, \mathrm{Ly}_{6 \mathrm{G}}{ }^{-}$, Ly6C $\mathrm{C}^{\text {high-low }}$ cells in antiviral immune response and viral clearance.

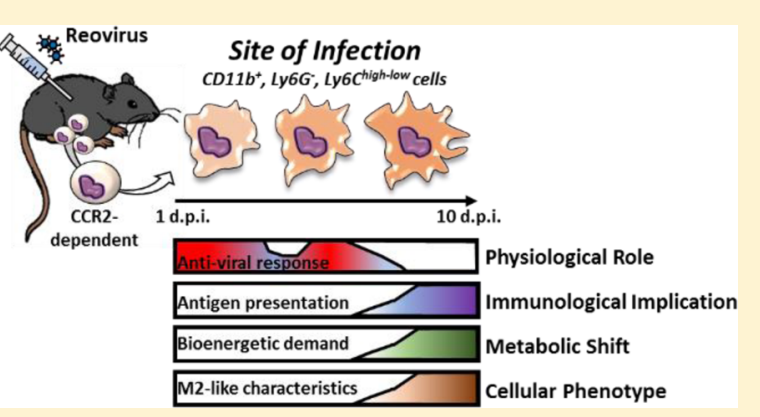
Most importantly, the time-resolved QTiPs data set showed the transition of $\mathrm{CD}_{11 \mathrm{~b}^{+}}, \mathrm{Ly} 6 \mathrm{G}^{-}$, Ly6 $\mathrm{C}^{\text {high-low }}$ cells into M2-like macrophages, which displayed increased antigen-presentation capacities and bioenergetic demands late in infection. We elucidated the pivotal role of myeloid cells in virus clearance and show how these cells phenotypically, functionally, and metabolically undergo a timely transition from inflammatory to M2-like macrophages in vivo. With respect to the growing appreciation for in vivo examination of viral-host interactions and for the role of myeloid cells, this study elucidates the use of quantitative proteomics to reveal the role and response of distinct immune cell populations throughout the course of virus infection.

KEYWORDS: myeloid cells, infection, proteomics, M2-like macrophages

\section{INTRODUCTION}

Myeloid immune cell populations are phenotypically dynamic and arise from a common pluripotent hematopoietic stem cell lineage. Following infection, bone marrow (BM)-emigrating immature monocytic myeloid cells-identified in mice as $\mathrm{CD}_{11} \mathrm{~b}^{+}, \mathrm{Ly} 6 \mathrm{G}^{-}, \mathrm{Ly} 6 \mathrm{C}^{+}$cells-are recruited to the site of infection and mediate antimicrobial, as well as inflammatory, functions. Importantly, site-specific environmental cues dictate the functionality and cellular phenotype of these myeloid cells, ranging from pro-inflammatory to immunosuppressive. It is hypothesized that, through a temporal transition, these inflammatory immature myeloid cells differentiate into monocytes and macrophages that acquire specific phenotypes, functionalities, and metabolic profiles throughout infection. Such plasticity permits these myeloid cells to be associated with a plethora of pathological conditions including pathogenic infections, ${ }^{1-3}$ inflammatory diseases/responses, ${ }^{4,5}$ cancer progression, ${ }^{6-9}$ and antitumor immune responses. ${ }^{10}$
Following infection, recruitment and transition of inflammatory $\mathrm{CD} 11 \mathrm{~b}^{+}, \mathrm{Ly}_{6 \mathrm{C}} \mathrm{C}^{+}$cells are instrumental in L. monocytogenes, ${ }^{2}$ K. pneumoniae, ${ }^{1}$ and influenza virus clearance. ${ }^{11}$ Although the exact mechanism of how inflammatory $\mathrm{CD}_{11 b^{+}}, \mathrm{Ly}_{6 \mathrm{G}}{ }^{-}, \mathrm{Ly}_{6 \mathrm{C}} \mathrm{C}^{+}$ cells contribute to pathogenic clearance is unclear, it is apparent that these cells are pivotal in both innate immunity as well as adaptive immunity. ${ }^{1,12}$ Thus, an in depth examination of their transitory, temporal, and stage-specific phenotype is necessary to understand the role and function of virus-driven inflammatory myeloid cells.

Changes in immune cell functions during infections are dependent on dynamic proteomic changes over time. Notwithstanding previous technological challenges, comprehensive and temporal characterization of proteomes to understand cellular function is now possible due to recent advancements in multiplex

Received: June 19, 2017

Published: August 3, 2017 
quantitative proteomics. ${ }^{13,14}$ Combined with novel synchronous precursor selection with three-stage mass spectrometry (SPSMS3) acquisition methods, extremely precise measurements of cellular proteomes are now possible. ${ }^{15,16}$ Although proteomic analysis has previously captured single time point "snapshots" of in vivo cell populations, in vivo dynamics of immune cell populations have not been explored. Here, we report a quantitative temporal in vivo proteomics (QTiPs) approach, which combines SPS-MS3-based 10-plex quantitative proteomics with flow cytometry-based cell sorting to precisely capture temporospatial proteomic changes of newly recruited, transitory $\mathrm{CD} 1 \mathrm{~b}^{+}$, Ly6G ${ }^{-}$, Ly6 $\mathrm{C}^{\text {high-low }}$ cells during reovirus infection.

Reovirus is a benign, enteric, human dsRNA virus that drives an acute viral infection and is readily cleared through an immunocompetent host. ${ }^{17}$ In addition to its use as a model of acute infection, reovirus is known for its potent preferential cancerkilling (also known as oncolytic) activities and is being tested as a therapeutic oncolytic virus in phase I, II, and III clinical trials internationally for the treatment of a variety of tumors. ${ }^{18-23}$ In this context, it is now clear that immunological events initiated following the administration of reovirus in immunocompetent hosts are the indispensable part of reovirus-based cancer therapy. Thus, the detailed understanding of immunological events initiated following viral infection is pertinent to the therapeutic effectiveness of oncolytic virus-based cancer immunotherapy. $^{24,25}$ Thus, using QTiPs combined with phenotypic, transcriptional, functional, and metabolic validations, we illustrate a temporal transition of reovirus-driven $\mathrm{CD}_{11} \mathrm{~b}^{+}, \mathrm{Ly}_{6} \mathrm{G}^{-}, \mathrm{Ly}_{6 \mathrm{C}}{ }^{+}$ cells from their role in innate antiviral immune response $\left(\mathrm{CD} 11 \mathrm{~b}^{+}, \mathrm{Ly}_{6 \mathrm{G}}^{-}\right.$, Ly6C $\mathrm{C}^{\text {high }}$ cells) to their acquisition of M2-like macrophage phenotype $\left(\mathrm{CD} 11 \mathrm{~b}^{+}, \mathrm{Ly} 6 \mathrm{G}^{-}, \mathrm{Ly} 6 \mathrm{C}^{\text {low }}\right.$ cells) during viral infection. Our QTiPs approach reports a novel platform to elucidate in depth, quantitative, temporospatial cellular transitions in the context of various pathophysiological conditions in situ. Our QTiPs approach reports a novel platform to elucidate in depth, quantitative, temporospatial cellular transitions in the context of various pathophysiological conditions in situ.

\section{EXPERIMENTAL SECTION}

\section{Antibodies and Reagents}

The following reagents used were purchased from Biolegend (San Diego, CA): FITC-antimouse Ly6G (1A8), Alexa Fluor 647-antimouse Ly6G (1A8), PE-antimouse Ly6C (Hk1.1), APC-antimouse Ly6C (Hk1.1), Alexa Fluor 647-antimouse CD206 (C068C2), PerCP/Cy5.5-antimouse CD11b (M1/70), Alexa Fluor 647-antimouse MHC-11 (I-A/I-E) (M5/114.15.2), and PE-antimouse H.2kb bound to SIINFEKL (25-D1.16). Antimouse CD16/32 (93) and APC-antimouse CCR2 (cat\# FAB5538a) were purchased from BioXCell (West Lebanon, $\mathrm{NH}$ ) and R\&D Systems (Minneapolis, MN), respectively. Metabolic stains, DAF-FM diacetate (4-amino-5-methylamino$2^{\prime}, 7^{\prime}$-difluorofluorescein diacetate) (D23844), and CM-H2DCFDA (C6827) were purchased from Molecular Probes (ThermoFisher Scientific, Rochford, IL, USA).

\section{Ethics Statement}

In vivo experimental procedures were approved by the Dalhousie University Animal Ethics Committee in accordance with the regulations/guidelines from the Canadian Council on Animal Care (CCAC) (project numbers 14-086 and 16-107). C57BL/6 mice were purchased from Charles River Laboratory (Montreal,
Quebec, Canada), and CCR2KO and C57BL/6-GFP mice were purchased from Jackson Laboratory (Bar Harbor, ME).

\section{QTiPs Sample Preparation and Analysis}

Animals were injected with reovirus as previously described, ${ }^{26,27}$ and inflammatory myeloid cells were collected from the site of infection as well as bone marrow on $1,3,5,7$, and 10 days postinfection (d.p.i.). Harvested cells were collected and stained as previously described ${ }^{26}$ and sorted using a FACSAria III (BD Biosciences), resulting in $\sim 95 \%$ purity. Isolated cells were washed with PBS, pelleted, and lysed in $6 \mathrm{M}$ guanidine- $\mathrm{HCl}$, $50 \mathrm{mM}$ HEPES, $\mathrm{pH} 8.5$, containing Roche complete mini protease inhibitor mixture ( 1 tablet per $10 \mathrm{~mL}$ ) (Roche, Madison, WI). Lysis was performed via sonication and cleared by centrifugation. Cysteine residues were reduced using $5 \mathrm{mM}$ dithiothreitol and then alkylated with $14 \mathrm{mM}$ iodoacetamide. Aliquots containing $50 \mu \mathrm{g}$ of protein were diluted to $1.5 \mathrm{M}$ guanidine- $\mathrm{HCl}, 50 \mathrm{mM}$ HEPES $(\mathrm{pH} 8.5$ ) and digested with trypsin (Promega, Madison, WI). Digested peptides were desalted using $60 \mathrm{mg}$ solid-phase C18-extraction cartridges (Waters, Milford, MA), lyophilized, and labeled using TMT 10-plex reagents as described previously. ${ }^{28}$ Samples were then mixed equally, desalted using solid-phase C18 extraction cartridges (Waters, Milford, MA), and lyophilized.

TMT10-labeled samples were fractionated using high-pH reversed phase chromatography performed with an Onyx monolithic $100 \times 4.6 \mathrm{~mm} \mathrm{C18}$ column (Phenomenex, Torrance, CA). The flow rate was $800 \mu \mathrm{L} / \mathrm{min}$, and a gradient of $5-40 \%$ acetonitrile ( $10 \mathrm{mM}$ ammonium formate, $\mathrm{pH} 8$ ) was applied over 60 min using an Agilent 1100 pump (Agilent) from which 12 fractions were collected. Fractions were desalted using homemade Stage Tips, ${ }^{29}$ lyophilized, and analyzed with an Orbitrap Fusion mass spectrometer (Thermo-Fisher Scientific, Rochford, IL) using the SPS-MS3 method as described previously. ${ }^{28,29}$ Protein identification was performed using a database search against a mouse proteome database (downloaded from UniProtKB in September 2014) concatenated to a mammalian orthoreovirus 3 (Dearing strain) database (downloaded from UniProtKB in September 2014). All false discovery rate (FDR) filtering and protein quantitation was performed as previously described. ${ }^{28}$ A protein was required to have a minimum total signal-to-noise of 100 in all TMT reporter channels, and the maximum number of missing channels was equal to 8 . Data for heat maps and individual protein profiles are represented by relative intensity, which is based on the summed signal-to-noise.

GO-annotation analysis was originally conducted on the whole data set using the open access Gene Ontology Consortium. ${ }^{30,31}$ The data set was subsequently analyzed via k-means clustering with Euclidean distance using MultiExperiment Viewer $(\mathrm{MeV})^{32}$ followed by DAVID Bioinformatics Resources (https://david. ncifcrf.gov/) to conduct GO-term analysis for BPs, MFs, and cellular compartments on specific clusters. Our total data set was utilized as the background for the data analysis searches. For the indicated experiments, the Interferome Web site ${ }^{33}$ and MitoCarta database ${ }^{34,35}$ were utilized to cross-list for proteins associated with interferon (IFN) response and mitochondrialassociated proteins, respectively. Insertion of individual clusters into the Interferome search engine identified IFN-associated proteins and classified such proteins into different IFN types. The mass spectrometry proteomics data (Data S-1) have been deposited into ProteomeXchange Consortium ${ }^{36}$ via the PRIDE $^{37}$ partner repository with the data set identifier PXD005064. 


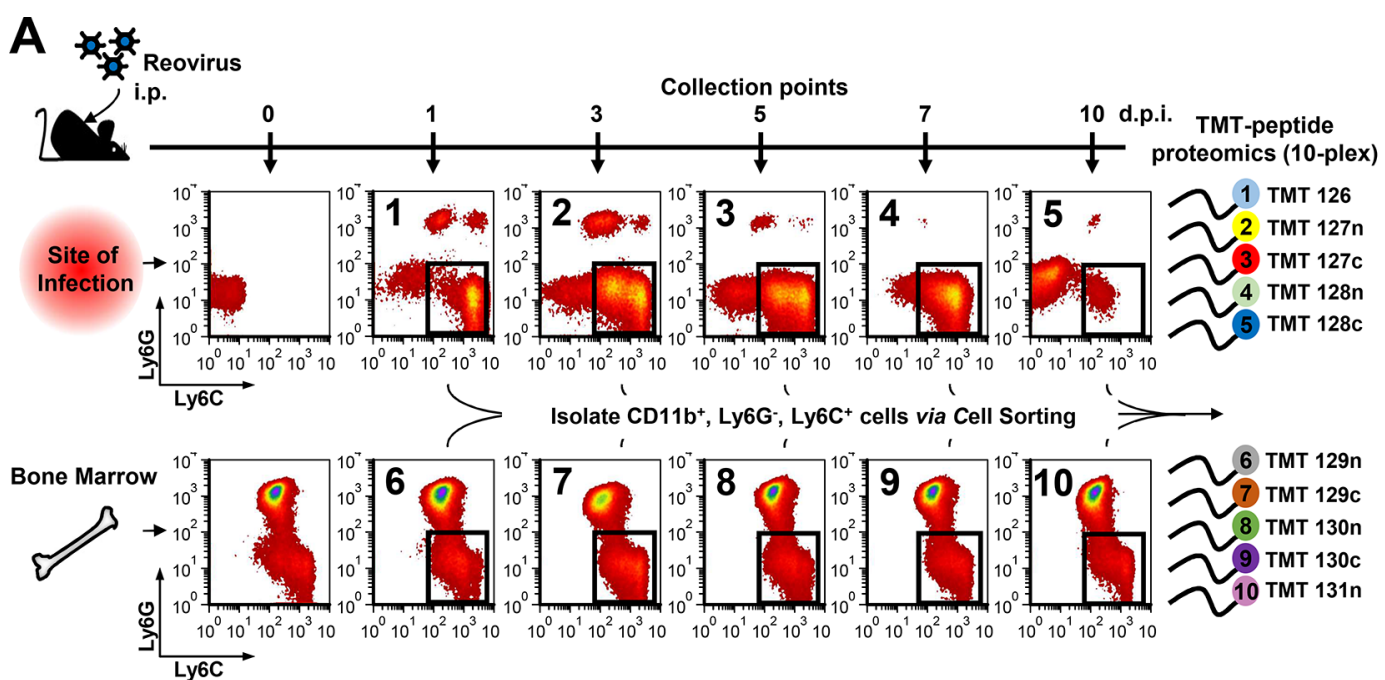

B

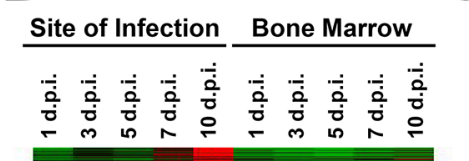

C

\section{Site of Infection}

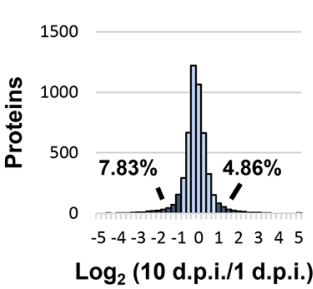

Bone Marrow

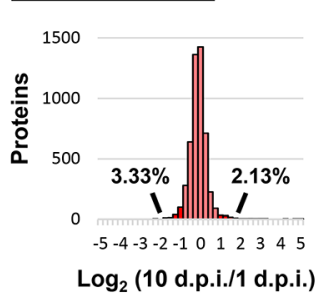

E

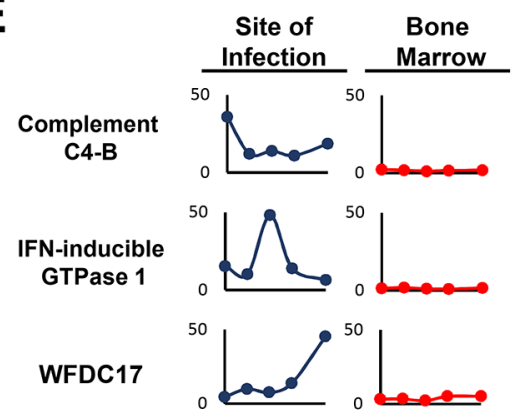

D
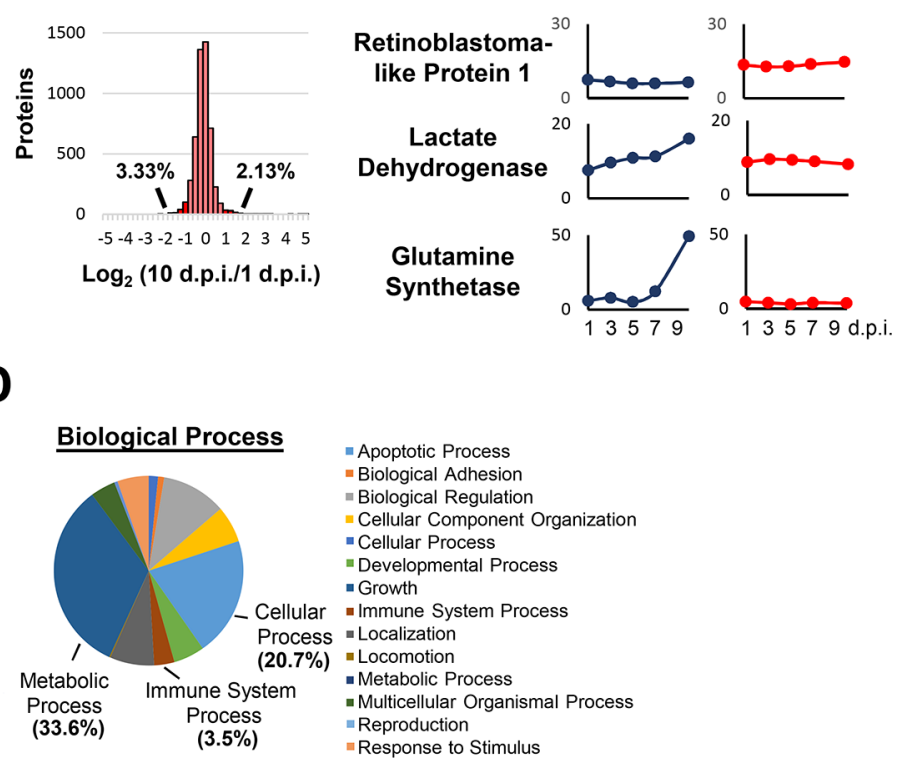

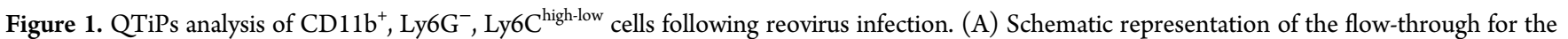
temporospatial proteomic approach combining fluorescence-activated cell sorting with TMT-mass spectrometry-based proteomics throughout viral infection (intraperitoneal injection [i.p.]). Dot plots represent the gating strategy and isolated population $\left(\mathrm{CD} 11 \mathrm{~b}^{+}, \mathrm{Ly}_{6} 6 \mathrm{G}^{-}\right.$, $\mathrm{Ly}_{6 \mathrm{C}} \mathrm{C}^{\text {high-low }}$ cells conserved within the black box) from each collection point from the SOI and BM. A pooled population of CD $11 \mathrm{~b}^{+}, \mathrm{Ly}_{6 \mathrm{G}}{ }^{-}, \mathrm{Ly} 6 \mathrm{C}^{\text {high-low }}$ myeloid cells were isolated from $10 \mathrm{C} 57 \mathrm{BL} / 6$ mice at $1,3,5,7$, and 10 d.p.i. (B) Relative intensity of total quantitative proteomic analysis of CD $11 \mathrm{~b}^{+}, \mathrm{Ly} 6 \mathrm{G}^{-}, \mathrm{Ly} 6 \mathrm{C}^{\text {high-low }}$ cells throughout infection in both the SOI and BM. (C) Comparing 10 to 1 d.p.i. SOI- and BM-isolated cells. (D) GO term enrichment analysis of the biological process terms of total proteomic analysis. (E) Representative protein intensity profiles of selective targets from the highlighted biological process terms (cellular process, immune system process, and metabolic process). 


\section{Flow Cytometry and Analysis}

Flow cytometry of harvested all immune cells from the spleen and bone marrow from independently collected animals as previously described. ${ }^{26}$ Peritoneal cavity (PC) cells were harvested via a flush of the PC with PBS. Flow cytometry for MHC-ova (SIINFEKL) was conducted by first pulsing unlabeled immune cells harvested from the PC with SIINFEKL peptide $(5 \mu \mathrm{g} / \mathrm{mL})$ for $2 \mathrm{~h}$ at $37^{\circ} \mathrm{C}$ in RPMI complete media (5\% vol/vol Glutamax, 10\% fetal bovine serum [FBS], $1 \times$ sodium pyruvate, $1 \times$ nonessential amino acids, and $1 \times$ Anti-Anti [Invitrogen, Carlsbad, CA]). Harvested cells (PC, spleen, and BM) were treated with RBC-lysing ammonium chloride (ACK) buffer, washed, and blocked with anti-CD16/32 antibody prior to primary antibody. For metabolic stains (NO and ROS), cells were incubated with $2.5 \mu \mathrm{M}$ DAF-FM diacetate (4-amino-5methylamino-2', $7^{\prime}$-difluorofluorescein diacetate) (D23844; Molecular Probes) or $2.5 \mu \mathrm{M}$ CM-H2DCFDA (C6827; Molecular Probes) for $30 \mathrm{~min}$ at $37{ }^{\circ} \mathrm{C}$ in combination with antibodies in flow cytometry running buffer (PBS-EDTA with 1\% FBS) (FACS buffer). Cells harvested for flow cytometry, with the exception of DAF-FM- or DCF-stained cells, were fixed with $4 \%$ PFA, washed, and resuspended in FACS buffer prior to analysis. Flow cytometry data were collected using a FACSCalibur flow cytometer (BD Bioscience), and analysis was conducted with the use of CellQuest Pro (BD Bioscience) and FCS Express V3 software (DeNovo Software, Los Angeles, CA).

\section{Reovirus Production and Plaque Assays}

Reovirus (serotype 3, Dearing strain) was cultured, amplified, and isolated using a previously established protocol. ${ }^{38}$ Reovirus was titered on L929 cells (American Type Culture Collection, Manassas, VA) by standard plaque assay as described previously. ${ }^{27,39}$ L929 cells were cultured in minimum essential media with $5 \%$ vol/vol Glutamax, $5 \%$ fetal bovine serum, $1 \times$ sodium pyruvate, $1 \times$ nonessential amino acids, and $1 \times$ Anti-Anti (Invitrogen, Carlsbad, CA). To assess the intra- and extracellular virus from the (site of infection) SOI, $5 \mathrm{~mL}$ of PBS was added to the peritoneal cavity. The resultant peritoneal flush was collected and spun down at $500 \mathrm{~g}$ for $6 \mathrm{~min}$ to separate the cells (for analysis of intracellular virus) from the extracellular fraction (contain-

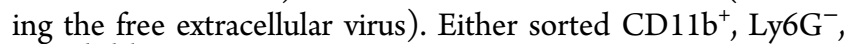
Ly6C ${ }^{\text {high-low }}$ cells or nonsorted cells (total heterogeneous population of cells) from such a peritoneal flush were lysed with RIPA buffer (0.05 M Tris-HCl, $\mathrm{pH} 7.4,0.15 \mathrm{M} \mathrm{NaCl}, 0.25 \%$ deoxycholic acid, 1\% NP-40, $1 \mathrm{mM}$ EDTA) to extract intracellular virus. To determine the viral titer (plaque forming units $/ \mathrm{mL}$ ), L929 cells were infected with a serial dilution of cell lysate or peritoneal flush supernatant. Virus titers were accessed $96 \mathrm{~h}$ post the initial L929 cell infection.

\section{Quantitative Real-Time PCR}

RNA extractions, cDNA synthesis, and qPCR were conducted as previously described ${ }^{26}$ on independently collected samples. The indicated gene-specific primers were purchased from Invitrogen. Data were analyzed using Livak and Schmittgen's $2^{-\Delta \Delta C T}$ method $^{40}$ and normalized to Gapdh.

\section{Extracellular Flux Analysis and Calculations}

Sorted cells $\left(5 \times 10^{5}\right.$ cells $)$, independently collected from a pooled population of 5-10 mice, were resuspended in XF media and plated onto X24 Seahorse cell plates coated with Cell-Tak (Corning). Oxygen consumption rate (OCR) and extracellular acidification rate (ECAR) were measured in XF assay media under basal conditions and in response to $1 \mu \mathrm{M}$ oligomycin,
$1.5 \mu \mathrm{M}$ carbonyl cyanide 4-(trifluoromethoxy)-phenylhydrazone (FCCP), $1 \mu \mathrm{M}$ rotenone, and $1 \mu \mathrm{M}$ antimycin A (all purchased from Sigma-Aldrich, ON, Canada) on the XF24 extracellular flux analyzer (Seahorse Bioscience, Billerica, MA, USA). Basal OCR was calculated by subtraction of the residual rate after antimycin A treatment. Maximal rate was calculated by subtraction of the residual rate after antimycin A treatment from FCCP-induced OCR. Proton leak was calculated as the difference between OCR after oligomycin treatment and OCR after antimycin A treatment. ATP production was calculated by subtraction of OCR after oligomycin treatment from basal OCR. Spare respiratory capacity was calculated by the difference between maximal OCR and basal OCR. Spare respiratory capacity coupling efficiency was calculated by the dividend of basal OCR and ATP production. Glycolytic capacity was calculated as the ECAR after oligomycin treatment. Glycolytic reserve was calculated by the difference between glycolytic capacity and ECAR. Glycolytic reserve percentage was calculated by the dividend of glycolytic capacity and ECAR.

\section{M1- and M2-like Macrophage Generation/Differentiation}

Bone marrow cells were collected from femur and tibia bones and cultured for 6-8 days in RPMI complete media supplemented with granulocyte macrophage colony-stimulating factor (20 ng/mL for M1-like macrophages) or macrophage colonystimulating factor (100 ng/mL for M2-like macrophages).

\section{Statistical Analysis}

Depending on the indicated experiment, one-way ANOVA with Bonferroni post-test or a two-tailed Student's $t$-test with $95 \%$ confidence interval were used for statistical analysis, and $p$ values of $<0.05$ were considered significant. Asterisks were used to signify $p$ values as not significant $(\mathrm{ns})=p>0.05,{ }^{*} p \leq 0.05, * * p$ $\leq 0.01$, and $* * * p \leq 0.001$.

\section{RESULTS}

\section{QTiPs of Virus-Induced CD11 b+, Ly6G- , Ly6Chigh Myeloid Cells}

Exposure to pathogens, especially viruses, drives the recruitment of $\mathrm{CD}_{11 \mathrm{~b}^{+}}, \mathrm{Ly}_{6 \mathrm{G}}$, Ly6 $\mathrm{C}^{\text {high }}$ myeloid cells that undergo functional transition at the site of infection. To directly visualize this transition of newly recruited, virus-induced myeloid cells in situ, we performed 10-plex quantitative mass spectrometry (MS) on temporally collected, cell-sorted, reovirus-driven myeloid cells. Reovirus induces the accumulation of otherwise absent $\mathrm{CD} 11 \mathrm{~b}^{+}, \mathrm{Ly}_{6 \mathrm{G}} \mathrm{C}^{-}, \mathrm{Ly} 6 \mathrm{C}^{\text {high }}$ cells at the site of infection as early as 1 d.p.i., which subsequently exhibited a gradual loss of Ly6C expression over time (hence the reference to these cells as $\mathrm{CD}_{11 \mathrm{~b}^{+}}, \mathrm{Ly}_{6 \mathrm{G}}{ }^{-}, \mathrm{Ly} 6 \mathrm{C}^{\text {high-low}}$; Figure $1 \mathrm{~A}$ and Figure S-1A-B). These $\mathrm{CD} 11 \mathrm{~b}^{+}, \mathrm{Ly}_{6 \mathrm{G}^{-}}$, Ly6C $\mathrm{C}^{\text {high-low }}$ cells were sorted from the site of infection (SOI, inflammatory) and the BM (resident) from $10 \mathrm{C} 57 \mathrm{BL} / 6$ mice per collection point. QTiPs analysis identified 6634 proteins and quantified 5019 proteins from the in vivo harvested and cell-sorted myeloid cell population spanning the course of 10 days in both the SOI and BM (Figure 1B, Data S-1). Comparing 10 to 1 d.p.i., SOI-isolated cells contained more proteomic changes ( $>$ - or $<2$-fold) than in the BM myeloid cells ( 12.69 vs $5.46 \%$, respectively) (Figure $1 \mathrm{C}$ ). Because the QTiPs data set provides rich temporal proteomic data, it can be interrogated further to reveal temporally distinct virus-driven myeloid cell changes over the course of acute infection.

Because of the limited knowledge of the overall proteomic sig-

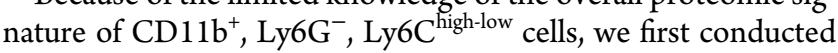


A

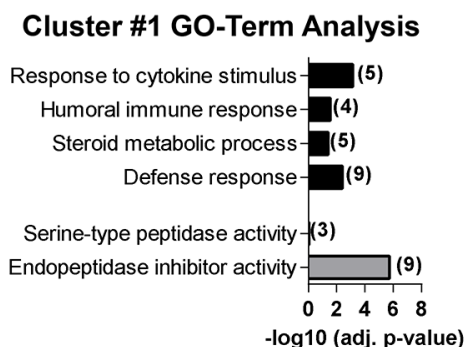

GO-TERM (BP) $\square$ GO-TERM (MF)

B

Cluster \#1 Protein Profiles

BP: Defense and Wound Damage Response

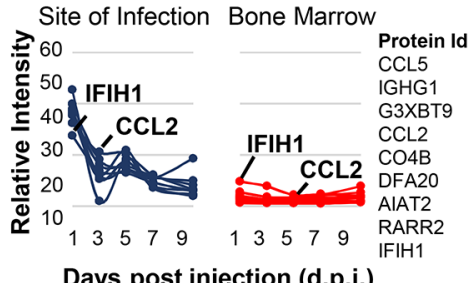

Days post injection (d.p.i.)

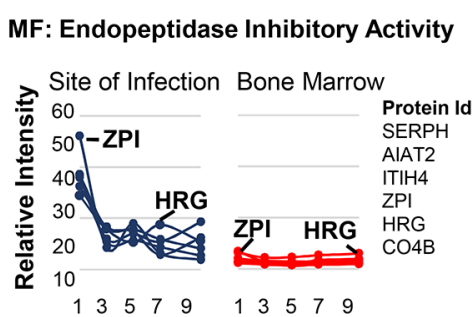

Days post injection (d.p.i.)
C

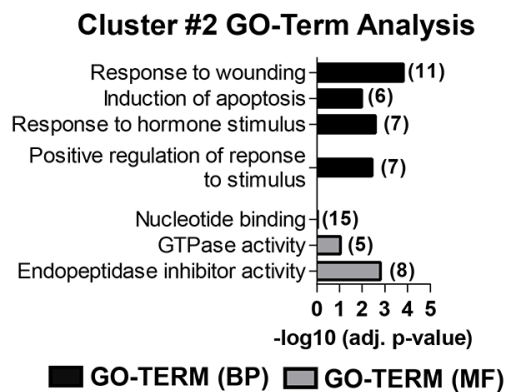

D

\section{Cluster \#2 Protein Profiles \\ BP: Wound, Hormone, and Positive Regulation to Stimulus}

Site of Infection Bone Marrow

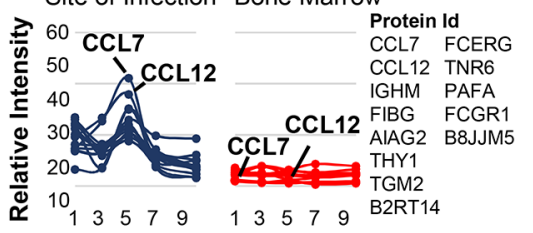

Days post injection (d.p.i.)

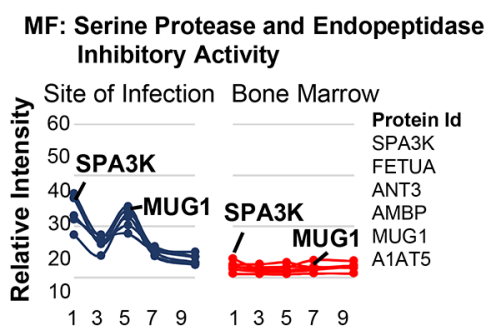

Days post injection (d.p.i.)
E
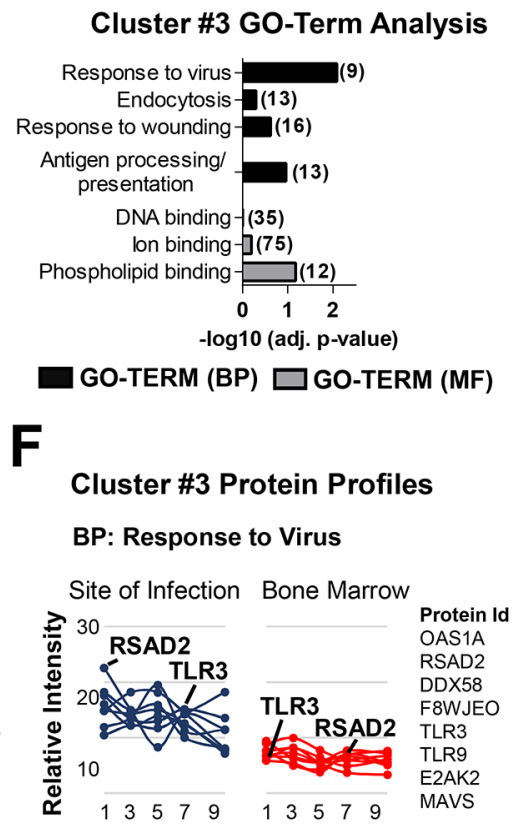

Days post injection (d.p.i.)

BP: Antigen Processing/Presentation

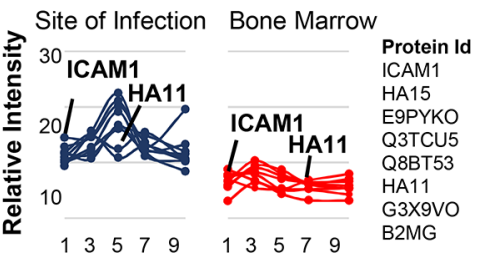

Days post injection (d.p.i.)

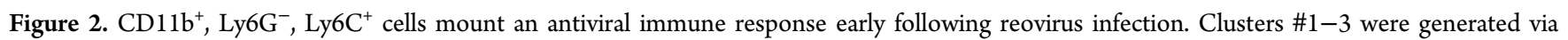
k-means cluster analyses using the Euclidean distance metric and are representative of three of ten clusters of the total proteomic analysis. GO annotation analysis of biological process (BP) and molecular function (MF) for clusters \#1 (A, B), \#2 (C, D), and \#3 (E, F) using DAVID bioinformatics are summarized in a bar graph and are represented as individual protein profiles for the indicated GO terms. Bar graphs illustrate the -log10 (adjusted [adj.] $p$-value) and number of identified targets per GO term (in brackets). These data are representative of a pooled cell-sorted population from $10 \mathrm{C} 57 \mathrm{BL} / 6$ mice per collection time point.

GO annotation analysis ${ }^{30,31}$ of all identified proteins in our data set. The most represented biological processes (BPs) were cellular (including cell cycle, proliferation, recognition, and growth) and metabolic (including catabolic, biosynthetic, and coenzyme) processes pertaining to 33.6 and $20.7 \%$ of the overall annotation analysis, respectively (Figure 1D and Figure S-1C). As anticipated, we observed immune system-associated BPs (Figure 1D), which encompassed antigen processing/presentation, immune response, and macrophage activation BPs (Figure S-1C). Investigation of BP-associated proteins identified temporal differences between the SOI and BM. For example, immune-associated proteins (complement C4-B, IFN-inducible GTPase 1, and activated macrophage/microglia WAP domain protein [WFDC17]) were predominantly higher in the SOI-isolated cells. Interestingly, unlike complement C4-B and IFN-inducible GTPase, which peak in relative abundance at 1 and 5 d.p.i., respectively. WFDC17 increased $\sim 10$-fold from 1 to 10 d.p.i., suggesting a timedependent discrepancy in immune function (Figure 1E). Additionally, numerous cell cycle-associated proteins (e.g., Retinoblastoma-like protein 1) were more abundant in BM-isolated fractions, proposing that cellular proliferation of these myeloid cells is greater in the BM. Because metabolic alterations can contribute to immune cell function/differentiation, we inspected the data set for metabolic proteins and observed a 2.1- and 8.4-fold induction of lactate dehydrogenase and glutamine synthetase, respectively, from 1 to 10 d.p.i. in SOI-isolated cells; however, no change was observed within the BM-isolated collections (Figure 1E). These changes suggest that SOI-isolated cells develop a more Warburg-like metabolism at 7 and 10 d.p.i.. Collectively, our QTiPs approach successfully captured temporal, quantitative, and spatially comparable proteomes of transitory myeloid cells directly from their in situ microenvironment.

Temporal Transition of Inflammatory CD11 b+ ${ }^{+}$, Ly6G ${ }^{-}$, Ly6C high Cells Aids in Viral Clearance

To understand distinct functions of virus-driven $\mathrm{CD} 11 \mathrm{~b}^{+}, \mathrm{Ly}_{6 \mathrm{G}} \mathrm{G}^{-}$, Ly6C ${ }^{\text {high }}$ cells, we clustered the data set using k-means clustering, revealing temporally distinct patterns of protein expression. Three of ten clusters contained proteins repressed over the period of 1-10 d.p.i. (Figure S-2). GO annotation analysis using DAVID bioinformatics ${ }^{41,42}$ of cluster \#1 (decreased expression patterns 
A

Cluster \#1:

Interferon-associated Proteins

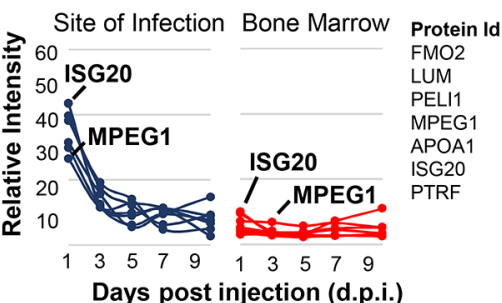

B

Cluster \#2:

Interferon-associated Proteins

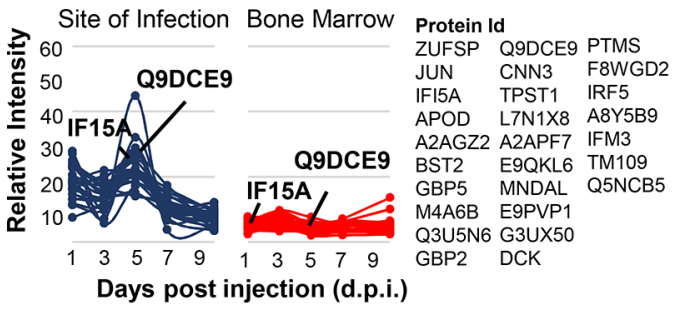

C

Cluster \#3:

Interferon-associated Proteins

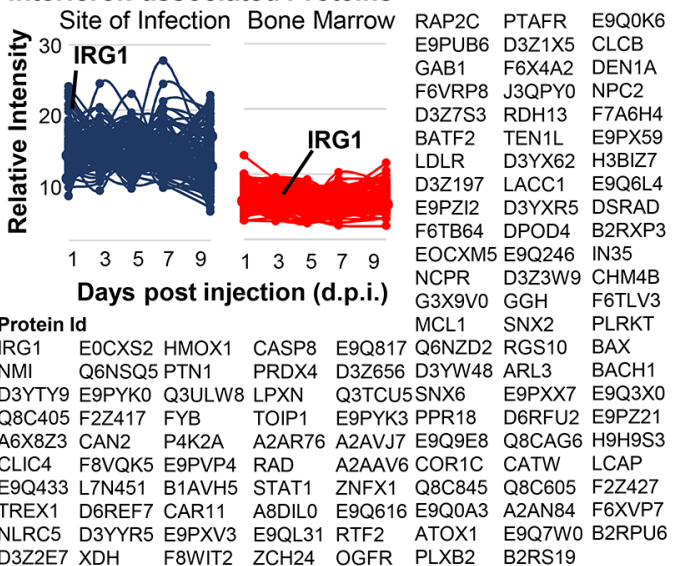

D
Isg56

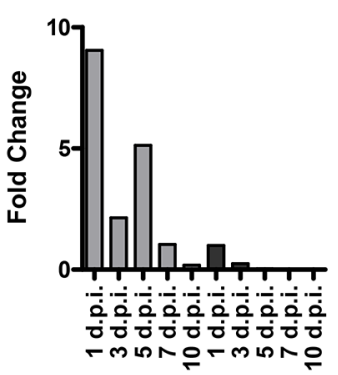

Serpina3k
Cd40

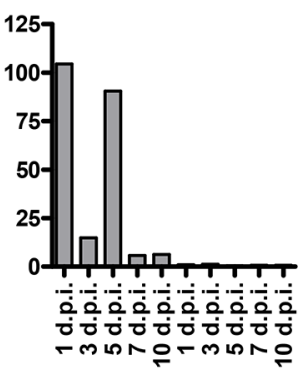

Ccl7

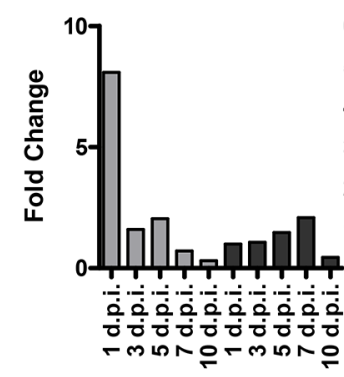

Irgm1

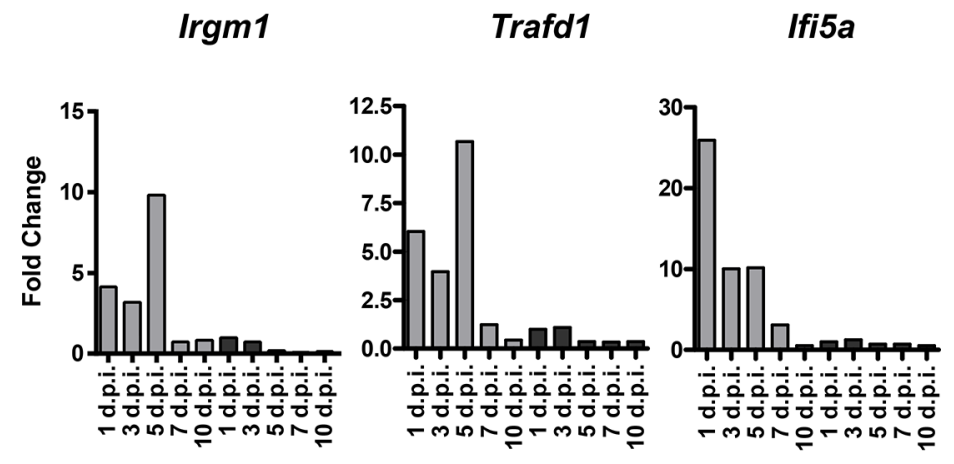

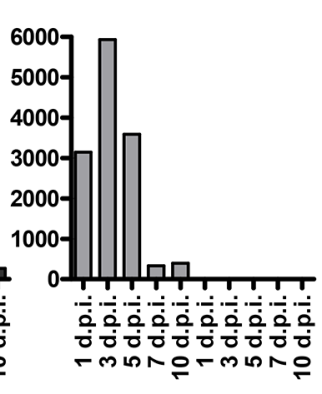

Trafd1
Igtp

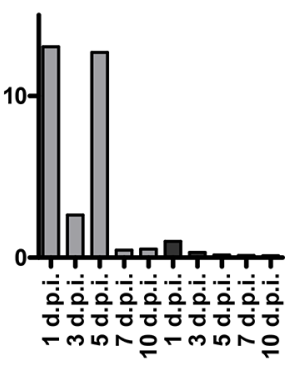

Ifit3
Site of Infection $\square$ Bone Marrow
E

Cluster \#1: Interferon-associated Proteins

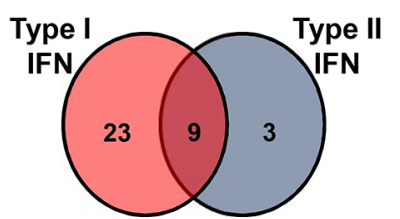

Cluster \#2: Interferon-associated Proteins

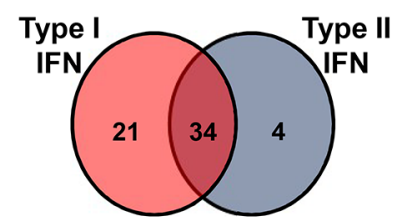

Cluster \#3:

Interferon-associated Proteins

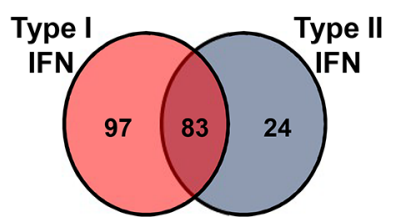

Figure 3. Reovirus-driven $\mathrm{CD}_{11 \mathrm{~b}^{+}}, \mathrm{Ly} 6 \mathrm{G}^{-}$, Ly6 $\mathrm{C}^{\text {high }}$ cells display a predominant type I IFN response during the early stages of infection. Individual protein profiles of selective IFN-associated proteins of cluster \#1 (A), \#2 (B), and \#3 (C) using an Interferome database of annotated IFN-associated proteins. (D) qRT-PCR validation of the indicated genes on isolated $\mathrm{CD} 11 \mathrm{~b}^{+}, \mathrm{Ly}_{6 \mathrm{G}}^{-}$, Ly $6 \mathrm{C}^{\text {high-low }}$ cells. Bars are the representative mean of $n=2$ of pooled populations of 5-10 mice per collection time point for both SOI- and BM-isolated cells, ran in duplicate and normalized to GAPDH, and compared to 1 d.p.i. BM sample to obtain the fold change. (E) Interferome database of annotated IFN-associated genes from clusters \#1-3 were represented in Venn diagram categorized with respect to type I-III IFN.

from 1 to 3 d.p.i.) showed an over-representation of BPs corresponding to response to cytokine stimulus, humoral immune response, defense response (e.g., IFIH1 and CCL2), and steroid metabolic processes (Figure 2A, B). Alongside these BPs, serinetype peptidase and endopeptidase inhibitor activity molecular functions (MFs) were over-represented within this cluster 
A

Lambda-2 (Reovirus)
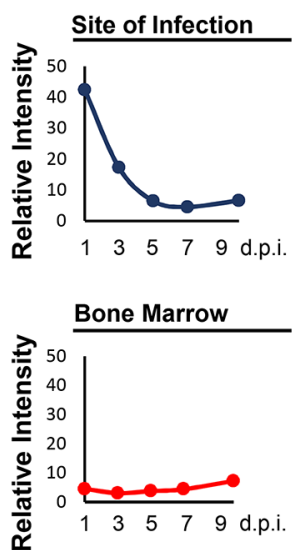

B

Intracellular Reovirus
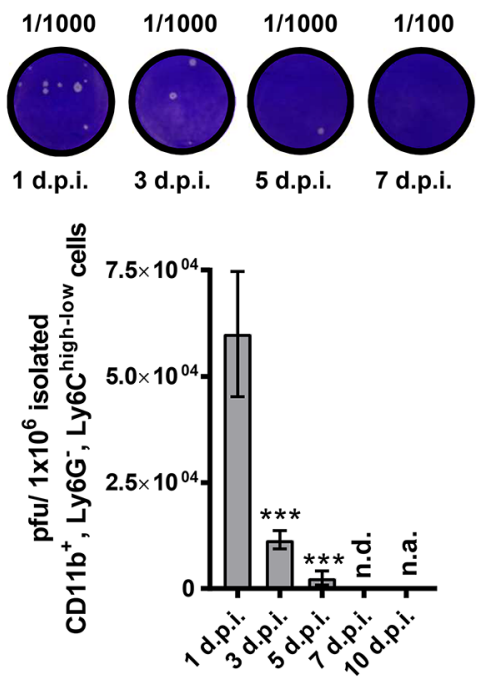

C

Extracellular Reovirus
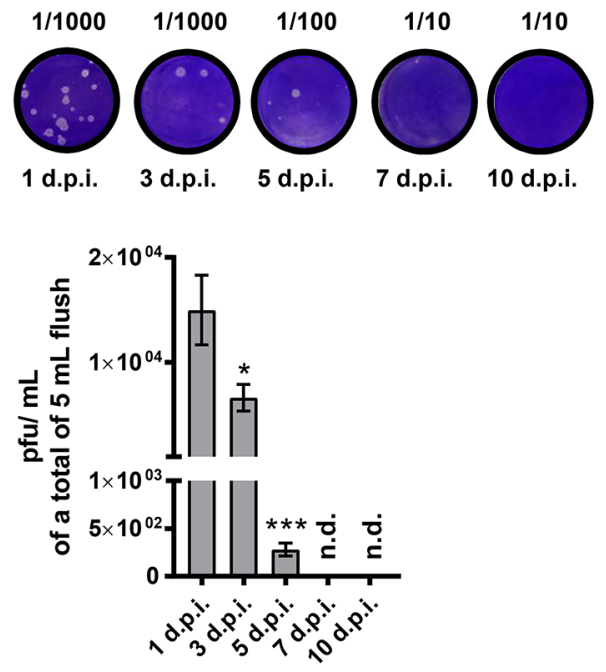

D

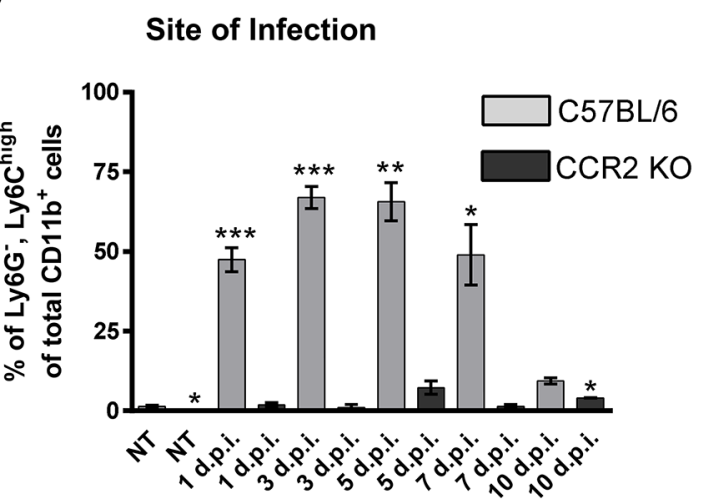

$E$

\section{Intracellular immune cell titer from PC}

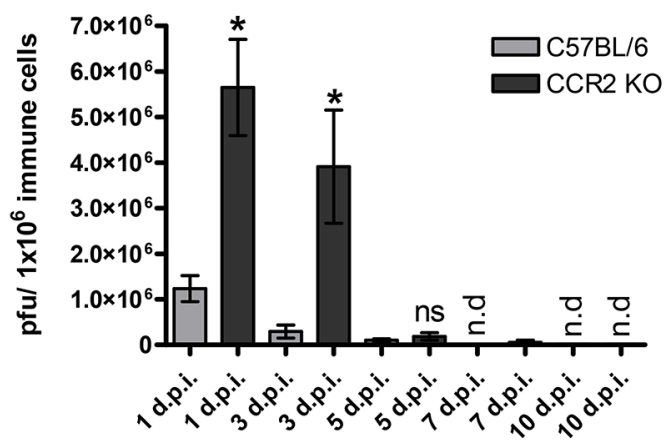

$\mathbf{F}$

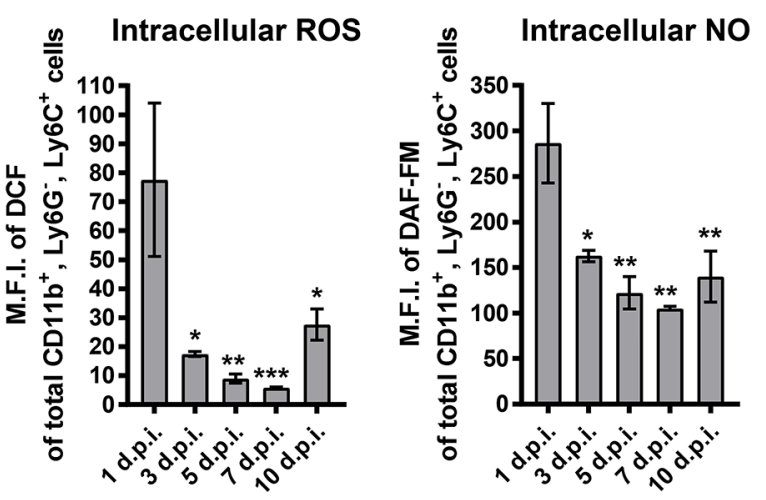

Figure 4. Reovirus-driven, CCR2-dependent recruitment/accumulation of $\mathrm{CD} 11 \mathrm{~b}^{+}$, $\mathrm{Ly}_{6 \mathrm{G}}{ }^{-}, \mathrm{Ly} 6 \mathrm{C}^{\text {high-low }}$ cells hinder viral persistence. (A) Proteomic identification and temporospatial quantitation of reovirus (lambda-2) protein. Temporal reovirus titers from intracellular reovirus (B) in isolated $\mathrm{CD}_{11 \mathrm{~b}^{+}, \mathrm{Ly}_{6 \mathrm{G}}}$, Ly6C $\mathrm{C}^{\text {high-low }}$ cells $\left(\mathrm{pfu} / 1 \times 10^{6}\right.$ cells) and extracellular reovirus $(\mathrm{C})$ collected from the SOI of reovirus infected animals at the d.p.i. (D) Flow cytometry analysis of $\mathrm{CD} 11 \mathrm{~b}^{+}, \mathrm{Ly} 6 \mathrm{G}^{-}, \mathrm{Ly} 6 \mathrm{C}^{\text {high-low }}$ cell frequency/kinetics from the SOI of wild-type C57BL/6 and CCR2KO mice. (E) Intracellular reovirus titers ( $\mathrm{pfu} / 1 \times 10^{6}$ immune cells) collected from the SOI of wild-type C57BL/6 and CCR2KO mice at the indicated time points post-injection. (F) Intracellular staining of ROS (DCF) and NO (DAF-FM) of CD11 b $\mathrm{b}^{+}, \mathrm{Ly}_{6 \mathrm{G}}{ }^{-}, \mathrm{Ly} 6 \mathrm{C}^{\text {high-low }}$ cells and shown as mean fluorescent intensity (M.F.I.). Graphs in B, C, E, and F are representative of mean \pm SEM with $n=5-6$ mice per collection. The graph in $\mathrm{D}$ is mean \pm SEM and representative of $n=30$ wild-type C57BL/ 6 mice and $n=3-8$ CCR2KO mice per collection point post-injection. One-way ANOVA with Bonferroni post-test (B-D and F) or two-tailed Student's $t$-test (E) with $95 \%$ confidence interval were used for statistical analysis, and $p$-values of $<0.05$ were considered significant. Asterisks were used to signify $p$-values as $* p \leq 0.05, * * p \leq 0.01$, and $* * * p \leq 0.001$. 
A

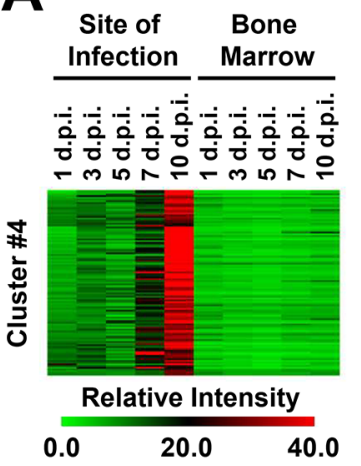

B

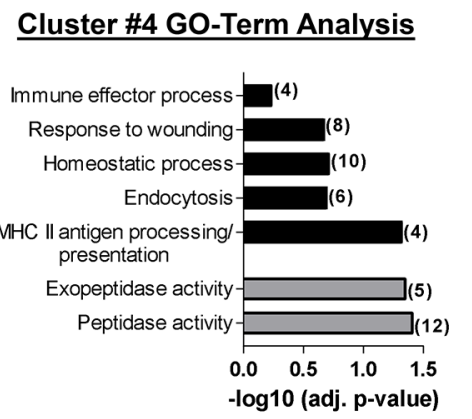

GO-TERM (BP) $\square$ GO-TERM (MF)
C

\section{Cluster \#4 Protein Profile}

MF: Peptidase Activity

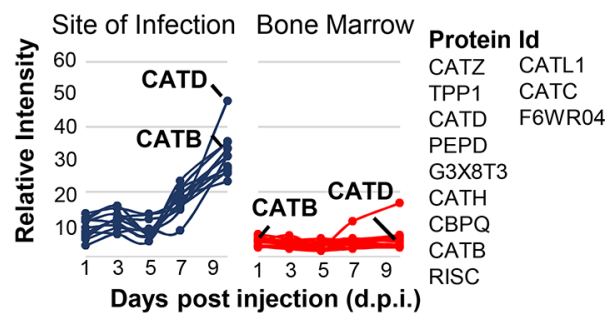

D

\section{Cluster \#4 Protein Profiles}

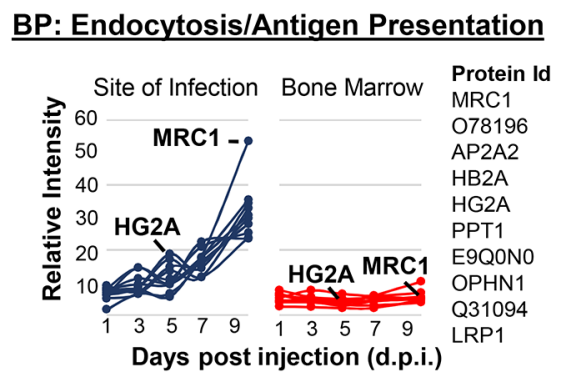

\section{BP: Response to Wounding}

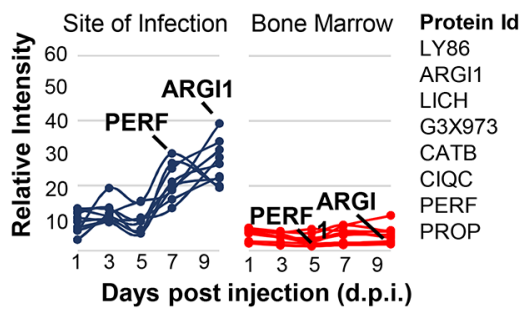

E

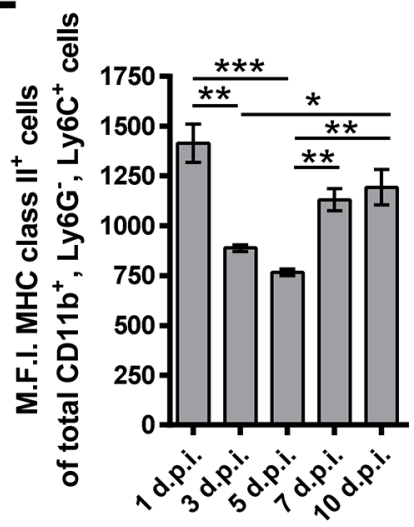

$\mathbf{F}$

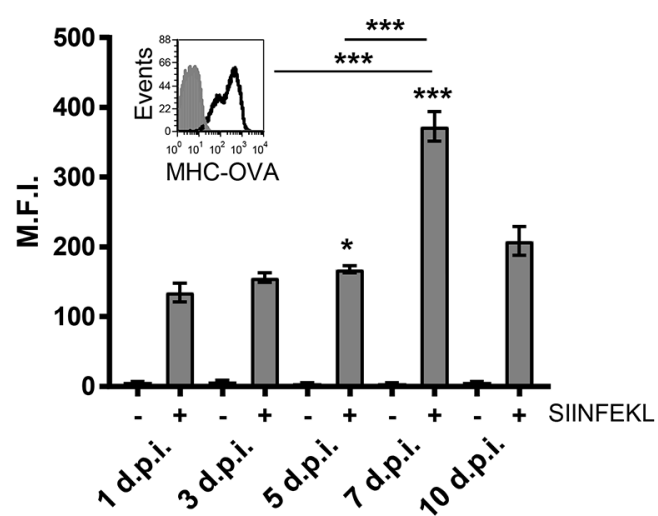

Figure 5. Reovirus-driven $\mathrm{CD}_{11 \mathrm{~b}^{+}}, \mathrm{Ly} 6 \mathrm{G}^{-}, \mathrm{Ly} 6 \mathrm{C}^{\text {high-low }}$ cells acquire increased antigen processing/presentation properties at later stages of infection. (A) K-means cluster analyses with Euclidean distance represented by relative intensity heat map of cluster \#4 (1 of 10 clusters) of the total proteomic analysis of $\mathrm{CD}_{11 \mathrm{~b}^{+}}$, Ly6G- $\mathrm{G}^{-}$Ly6 $\mathrm{C}^{\text {high-low }}$ cells (illustrated in Figure 1B). (B) GO annotation analysis of BP and MF for cluster \#4 using DAVID bioinformatics, summarized in bar graph, illustrating the $-\log 10$ (adjusted [adj.] $p$-value), and number of identified targets per GO term (in brackets). $(\mathrm{C}, \mathrm{D})$ Individual protein profiles of the indicated MF and BP, respectively. Flow cytometry analysis of the MHC class II (E) and MHC class I-OVA (F) surface expression (represented in M.F.I.) of $\mathrm{CD}_{11 \mathrm{~b}^{+}}, \mathrm{Ly} 6 \mathrm{G}^{-}, \mathrm{Ly} 6 \mathrm{C}^{\text {high-low }}$ myeloid cells throughout the course of infection. Ova peptide (SIINFEKL) pulsed $\mathrm{CD} 11 \mathrm{~b}^{+}, \mathrm{Ly} 6 \mathrm{G}^{-}, \mathrm{Ly} 6 \mathrm{C}^{\text {high-low }}$ myeloid cells were analyzed for MHC class I-OVA (mean fluorescent intensity, M.F.I.) at the indicated collections post. These experiments (E, F) are representative bar graphs of mean \pm SEM with $n=3-5$. One-way ANOVA with Bonferroni post-test (E, F) with a $95 \%$ confidence interval were used for statistical analysis, and $p$-values of $<0.05$ were considered significant. Asterisks were used to signify $p$-values as $* p \leq 0.05, * * p \leq 0.01$, and $* * * p \leq 0.001$.

(e.g., ZP1 and HRG). In cluster \#2 (expression peak at 5 d.p.i.), we observed an over-representation of response to wounding, response to stimulus (hormone and positive regulation) (e.g., CCL7 and CCL12), and endopeptidase inhibitor activity (e.g., SPA3K and MUG1) (Figure 2C, D). These data suggest that SOI-isolated cells are early responders to viral infection. Furthermore, cluster \#3 represented proteins with a general elevated relative intensity within SOI- vs BM-isolated cells. GO annotation of cluster \#3 showed an over-representation of BP-associated categories for the response to virus (e.g., RSAD2 and toll-like receptor 3 [TLR3]), response to wounding, endocytosis, and antigen processing/presentation (e.g., ICAM1 and HA11) (Figure 2E, F). Specifically, cluster \#3 contained hallmark viral infection-associated immunological targets, such as $2^{\prime}-5^{\prime}$-oligoadenylate synthase 1A (OAS1A), TLR3, TLR9, H-2 Class-I histocompatibility antigen, $\beta$-2-microglobulin, and ICAM1. Collectively, this 
analysis reveals a time-dependent transition of inflammatory

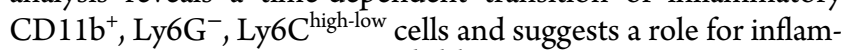
matory $\mathrm{CD} 11 \mathrm{~b}^{+}, \mathrm{Ly} 6 \mathrm{G}^{-}$, Ly $6 \mathrm{C}^{\text {high-low }}$ cells in antiviral immunity.

Considering that reovirus exposure stimulates pattern recognition receptors (PRRs), especially toll-like receptor 3 (TLR-3), and produces a type I IFN response, clusters \#1-3 were additionally analyzed using an Interferome database. ${ }^{33}$ This analysis revealed profiles for numerous IFN-associated genes (e.g., ISG20, MPEG1, IFI5A, Q9DCE9, and IRG1) (Figure 3A-C). Gene-specific RT-PCR amplification of Isg56, Cd40, Igtp, Serpina3k, Ccl7, Ifit3, Irgm 1, Trafd1, and Ifi5a showed compatible mRNA expression trends with that of their respective protein expression profiles from clusters \#1-3 (Figure 3D). Importantly, temporal changes in IFN-associated protein expression were mostly within SOI-isolated cells as opposed to their BM-isolated counterparts. Categorizing these IFN-associated proteins into type I and II responses emphasizes a predominant type I IFN-response from SOI-isolated cells early following infection in addition to a secondary elevation in type II IFN-associated proteins (shown in cluster \#2) (Figure 3E). Together, these results suggest that $\mathrm{CD} 11 \mathrm{~b}^{+}, \mathrm{Ly} 6 \mathrm{G}^{-}, \mathrm{Ly} 6 \mathrm{C}^{\text {high-low }}$ cells contribute to type I and type II IFN response following infection.

On the basis of the temporal IFN response associated with $\mathrm{CD}_{11} \mathrm{~b}^{+}, \mathrm{Ly} 6 \mathrm{G}^{-}, \mathrm{Ly} 6 \mathrm{C}^{\text {high-low }}$ cells, we next sought to determine if they affect viral replication. First, we investigated the viral titers of reovirus within $\mathrm{CD}_{11 \mathrm{~b}^{+}}, \mathrm{Ly}_{6 \mathrm{G}}^{-}$, Ly6C high-low cells (intracellular) as well as those present within the SOI (extracellular). In congruence with the reoviral lambda protein expression profile captured within the QTiPs data (Figure 4A), plaque assaybased analysis for the intracellular and extracellular virus showed the highest viral titers at 1 d.p.i. that steadily declined over the course of 10 days (Figure 4B, C). These data demonstrated the ability of inflammatory CD $11 b^{+}, \mathrm{Ly}_{6} \mathrm{G}^{-}, \mathrm{Ly} 6 \mathrm{C}^{\text {high-low }}$ cells to harbor reovirus in a time-dependent manner. In the context of the proposed role for such myeloid cells as oncolytic virus carriers, ${ }^{4-45}$ these findings bear clinical relevance.

Because the SOI contains a diverse mixture of immune cells, we wanted to delineate whether the CD11b ${ }^{+}, \mathrm{Ly}_{6 \mathrm{G}^{-}}, \mathrm{Ly}_{6 \mathrm{C}}$ high-low cells specifically affect viral persistence. For this purpose, we used a well-documented CCR2 $\mathrm{KO}$ mouse model in which the trafficking of inflammatory myeloid cells from the BM to the SOI is defective. ${ }^{2}$ Importantly, this characteristic of impaired trafficking of inflammatory myeloid cells in CCR2 $\mathrm{KO}$ mice is routinely used to identify the contribution of myeloid cells during viral, bacterial, and parasitic infections. ${ }^{11,12,37,38}$ Thus, we first conducted comparative frequency/kinetic analysis of reovirusdriven $\mathrm{CD}_{11 \mathrm{~b}^{+}}, \mathrm{Ly}_{6 \mathrm{G}}^{-}$, Ly6C $\mathrm{C}^{\text {high-low }}$ cells in wild-type (WT) $\mathrm{C} 57 \mathrm{BL} / 6$ versus CCR2KO mice and showed a near absence of $\mathrm{CD} 11 \mathrm{~b}^{+}, \mathrm{Ly}_{6 \mathrm{G}^{-}}$, Ly6C $\mathrm{C}^{\text {high-low }}$ cell accumulation within the SOI of CCR2KO mice (Figure 4D), confirming the requirement of CCR2 for the recruitment of CD11b ${ }^{+}, \mathrm{Ly}_{6} \mathrm{G}^{-}, \mathrm{Ly} 6 \mathrm{C}^{\text {high-low }}$ cells at the SOI. No significant frequency/kinetics differences for these cells were observed within the spleen and BM of WT vs CCR2KO mice (Figure S-3A). Furthermore, the comparative intracellular virus load analysis on total SOI-collected immune cells illustrated significantly higher titer of replication-competent reovirus in CCR2 KO mice (which contain a lower number of

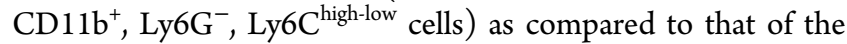
WT mice (Figure 4E) and suggested an antiviral role for inflammatory myeloid cells. It should also be noted that these inflammatory cells also contain the known antiviral mediators including reactive oxygen species (ROS) and nitric oxide (NO), especially at 1 d.p.i. (Figure $4 \mathrm{~F}$ ). Together, these analyses validate the QTiPs-revealed role for $\mathrm{CD}_{11} \mathrm{~b}^{+}, \mathrm{Ly}_{6 \mathrm{G}}{ }^{-}, \mathrm{Ly} 6 \mathrm{C}^{\text {high-low }}$ cells in viral clearance.

\section{Virus-Driven CD11b+, Ly6G ${ }^{-}$, Ly6C ${ }^{\text {high }}$ Cells Acquire Enhanced Antigen Presentation Characteristics}

A particularly interesting cluster of proteins, showed delayed (7-10 d.p.i.) increased abundance in SOI- but not BM-isolated CD $11 b^{+}$, Ly6G $^{-}$, Ly6C $\mathrm{C}^{\text {high-low }}$ cells (Figure 5A, cluster \#4). GO annotation of cluster \#4 illustrated an increased peptidase activity (MF) within these cells during the later stages of infection, which included antigen processing/presentation-associated proteins, such as Cathepsin B (CATB) and Cathepsin D (CATD), that are essential to drive an effective adaptive immune response (Figure 5B, C). ${ }^{46} \mathrm{GO}$ annotation also revealed an over-representation of MFs of the immune effector process, response to wounding (e.g., PERF and ARGI1), homeostatic process, endocytosis, and major histocompatibility complex (MHC)-II antigen processing/presentation (e.g., MRC1 and HG2A) in SOI-isolated cells (Figure 5B, D). qRT-PCR-based validation of many of these targets showed consistent temporal gene expression patterns for genes Mrc1, Pepd, H2-ab1, Cd74, Tpp1, and Lip1 (Figure S-3B). Together, the QTiPs suggested the acquisition of antigen-presentation capabilities by inflammatory $\mathrm{CD}_{11 b^{+}}$, Ly6G ${ }^{-}$, Ly6C $\mathrm{C}^{\text {high-low }}$ cells late during infection.

To validate this hypothesis, we examined MHC-II surface expression on $\mathrm{CD}_{11 \mathrm{~b}^{+}}$, $\mathrm{Ly}_{6 \mathrm{G}}{ }^{-}$, Ly6C $\mathrm{C}^{\text {high-low }}$ cells during infection. Congruent with our proteomics data, these cells demonstrated higher surface expression of MHC-II at 7-10 d.p.i. compared to those at 3 and 5 d.p.i.; however, it was interesting to note that these cells were initially recruited with elevated MHC-II expression at 1 d.p.i. (Figure 5E). Finally, to demonstrate the antigen presentation capacity, we monitored the ability of virusdriven $\mathrm{CD} 11 \mathrm{~b}^{+}, \mathrm{Ly}_{6 \mathrm{G}}{ }^{-}$, $\mathrm{Ly}_{6} \mathrm{C}^{\text {high-low }}$ cells to present the immunodominant epitope of ovalbumin (OVA; peptide SIINFEKL) in the context of MHC-I. Importantly, CD11b ${ }^{+}, \mathrm{Ly}_{6 \mathrm{G}}$,, Ly6C $\mathrm{C}^{\text {high-low }}$ cells showed the highest capacity to present SIINFEKL at 7 d.p.i. (Figure $5 \mathrm{~F}$ ). Altogether, our data suggest that inflammatory CD $11 b^{+}$, Ly $6 G^{-}$, Ly6 $C^{\text {high-low }}$ cells undergo a phenotypic and functional transition to acquire enhanced antigen processing/ presentation abilities during the later stage of infection.

\section{Metabolic Reprogramming Accompanies Inflammatory

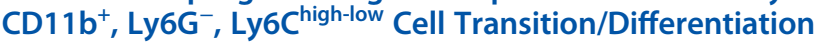

Because of the connection between distinct metabolic pathways and myeloid cell functional capacities, and based on the QTiPsidentified induction of proteins regulating metabolism (e.g., LDHA), we also assessed the metabolic profiles of transitory $\mathrm{CD}_{11 \mathrm{~b}^{+}}, \mathrm{Ly}_{6 \mathrm{G}}^{-}, \mathrm{Ly} 6 \mathrm{C}^{\text {high-low }}$ cells. Metabolic-associated proteins (indicated by BPs and cellular compartment GO annotation analysis) were evident in cluster \#5 with an increasing trend from 1 to 10 d.p.i. in SOI-isolated cells (Figure S-4A-C). We compared our QTiPs data set to the mouse MitoCarta2.0 data $\operatorname{set}^{34,35}$ to exclusively examine known mitochondrial proteins. Using k-means clustering, we subdivided the total mitochondria-associated proteomic data into various clusters (Mitoclusters \#1-10; Figure 6A and Figure S-5). GO annotation analysis of Mito-clusters \#1 and 2 showed an over-representation of proteins involved in cellular response to ROS, the fatty acid metabolic process, response to oxidative stress, and generation of precursor metabolites and energy (Figure S-6A). KEGG pathway analysis $^{41,42}$ of Mito-clusters \#1-2 showed an over-representation of fatty acid metabolism, oxidative phosphorylation, and the citric acid cycle (Figure S-6A), and STRING network analysis ${ }^{47}$ further illustrated the interaction of these pathways among all 
A

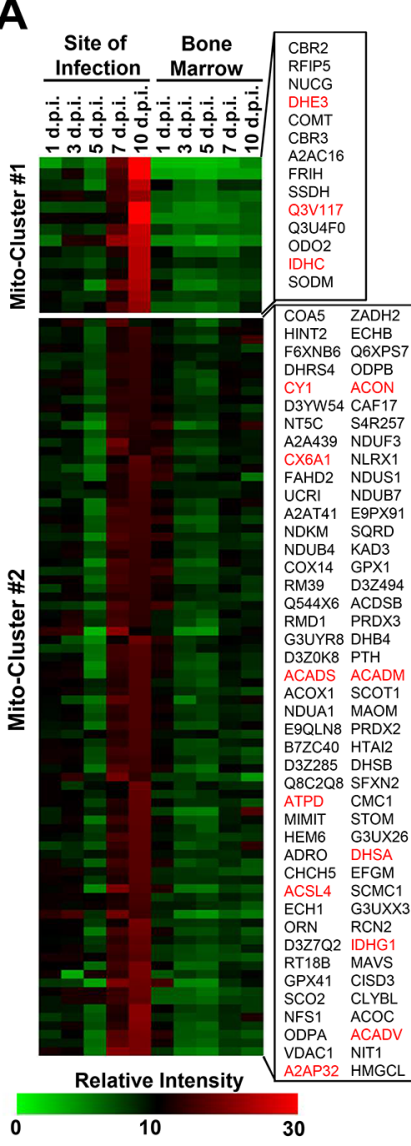

0
B

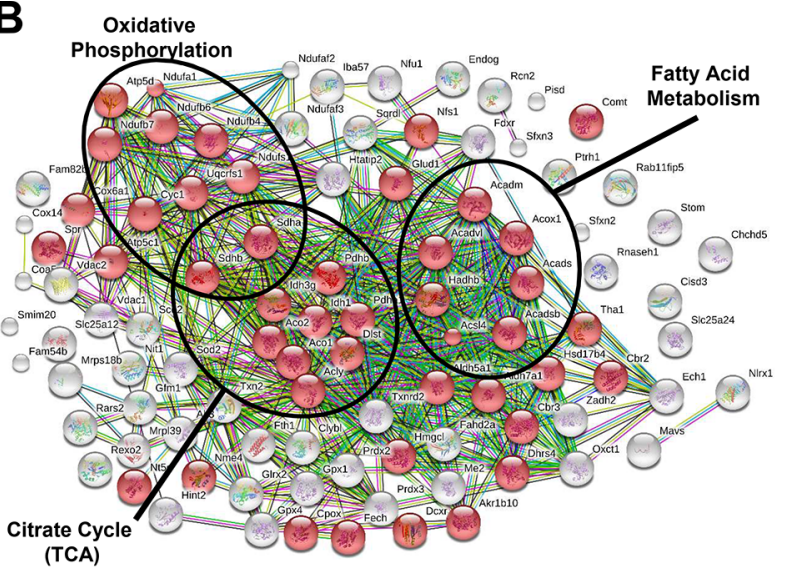

C
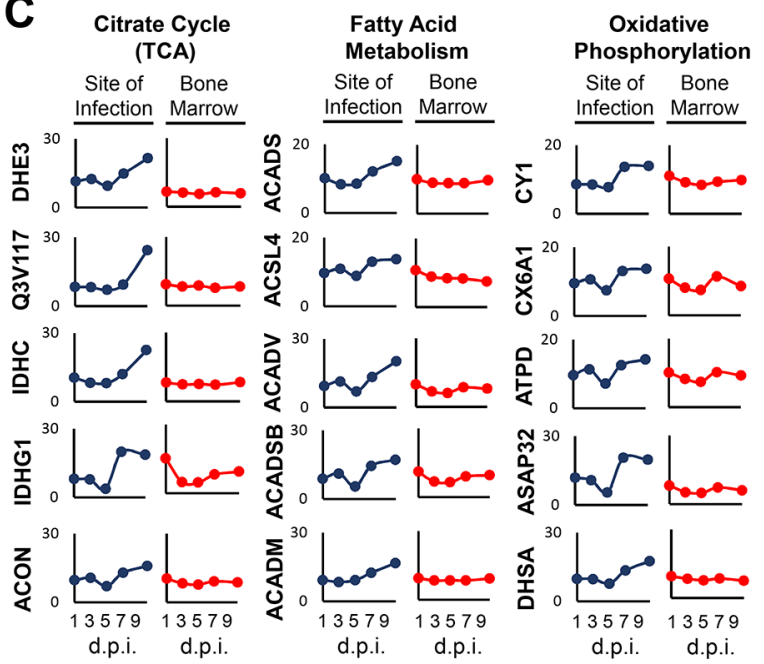

$\mathbf{F}$

G

E
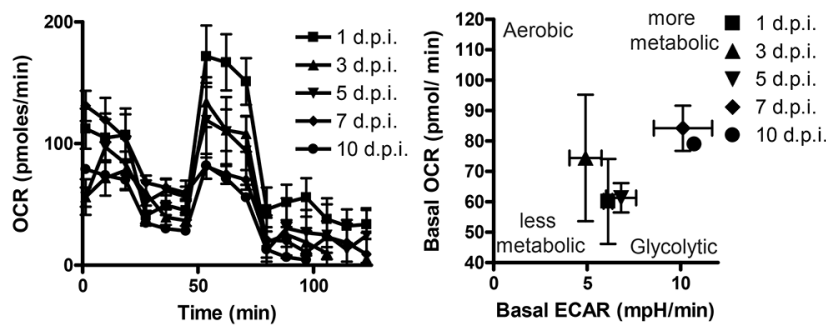

Spare Respiratory Capacity (\%)
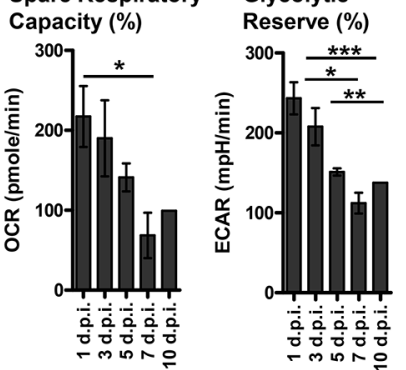

Figure 6. Temporal metabolic reprogramming of inflammatory $\mathrm{CD} 11 \mathrm{~b}^{+}, \mathrm{Ly} 6 \mathrm{G}^{-}, \mathrm{Ly} 6 \mathrm{C}^{\text {high-low }}$ cells. (A) Comparison of the total proteomic data set with MitoCarta2.0 data set to generate clusters via k-means clustering and Euclidean distance analysis. Selected 2 of 10 clusters are illustrated via heat map with indicated protein IDs. (B) String network analysis of Mito-cluster \#1 and 2 illustrating metabolic pathway-associated proteins in red, and encircled are the identified proteins associated with the indicated KEGG pathway and their interactions. (C) Individual protein profiles (also highlighted in red in A) pertaining to the indicated KEGG pathways. (D) OCR of isolated cells for each collection point. Basal OCR and ECAR graphically represented (E) and summarized for the spare respiratory capacity (\%) (F) and glycolytic reserve (\%) (G). Graphs in D-G are data represented as mean \pm SEM and collected from $n=1-4$ each with a pooled population from 5 to 10 mice. One-way ANOVA with Bonferroni post-test (F-H) with $95 \%$ confidence interval were used for statistical analysis, and $p$-values of $<0.05$ were considered significant. Asterisks were used to signify $p$-values as $* p \leq 0.05$, $* * p \leq 0.01$, and $* * * p \leq 0.001$.

metabolic pathway-associated proteins (shown in red) within these clusters (Figure 6B). Individual protein profile analysis from Mito-clusters \#1 and 2 of the citrate acid cycle, fatty acid metabolism, and oxidative phosphorylation revealed a general increasing trend from 1 to 10 d.p.i. (Figure 6C). These analyses highlight the metabolic reprogramming of inflammatory $\mathrm{CD}_{11 \mathrm{~b}^{+}}$, Ly6G ${ }^{-}$, Ly6C $\mathrm{C}^{\text {high-low }}$ cells following viral infection.
Because the proteomic data suggested a metabolic switch in SOI-isolated $\mathrm{CD}_{11 \mathrm{~b}^{+}}$, Ly6G ${ }^{-}$, Ly6 $\mathrm{C}^{\text {high-low }}$ cells, especially at 7-10 d.p.i., we examined time-dependent cellular bioenergetics (mitochondrial respiration and glycolysis) (Figure 6D and Figure S-6B) in isolated $\mathrm{CD}_{11 \mathrm{~b}^{+}}, \mathrm{Ly} 6 \mathrm{G}^{-}$, Ly6C $\mathrm{C}^{\text {high-low }}$ cells. As shown in Figure $6 \mathrm{E}$ and Figure S-6C, SOI isolated cells displayed the highest basal oxygen consumption rate (OCR), ATP produc- 
A
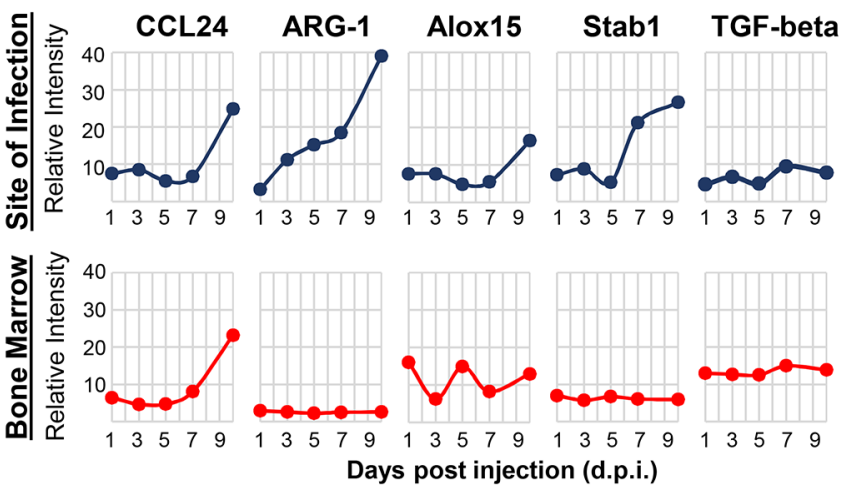

Days post injection (d.p.i.)
B
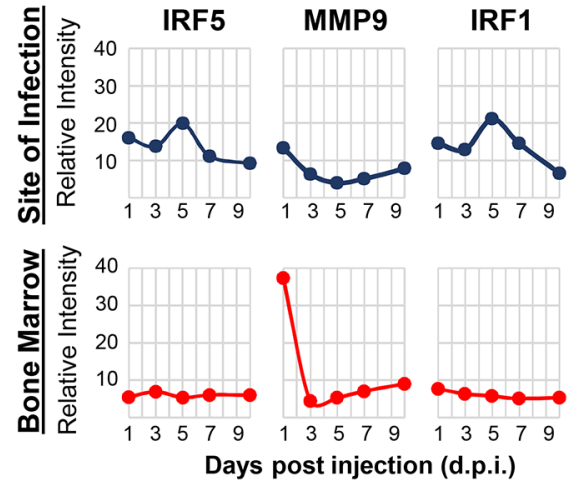

F

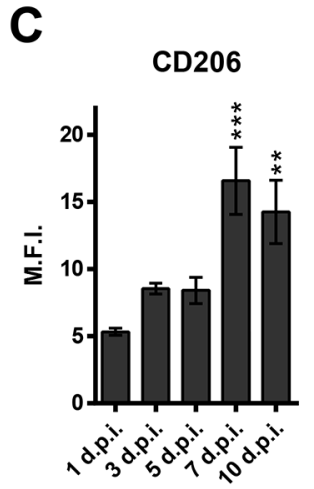

D

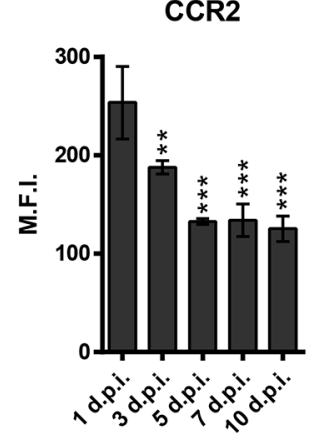

E

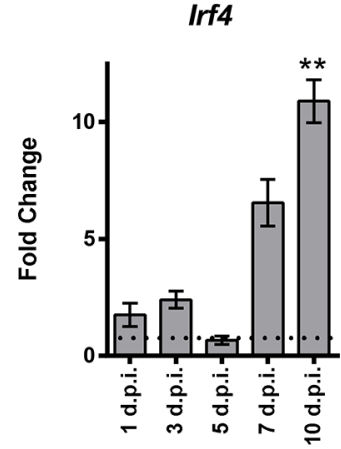

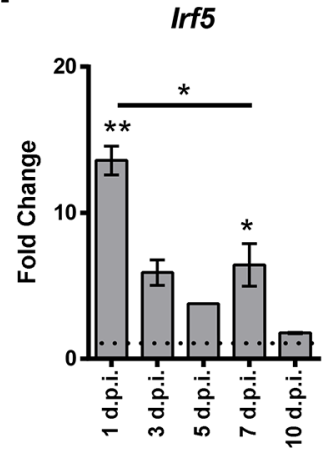

G

H

Ccl17

Cd86

|I-1 $\beta$

Cd68

Socs1

Tnfa

Ifny
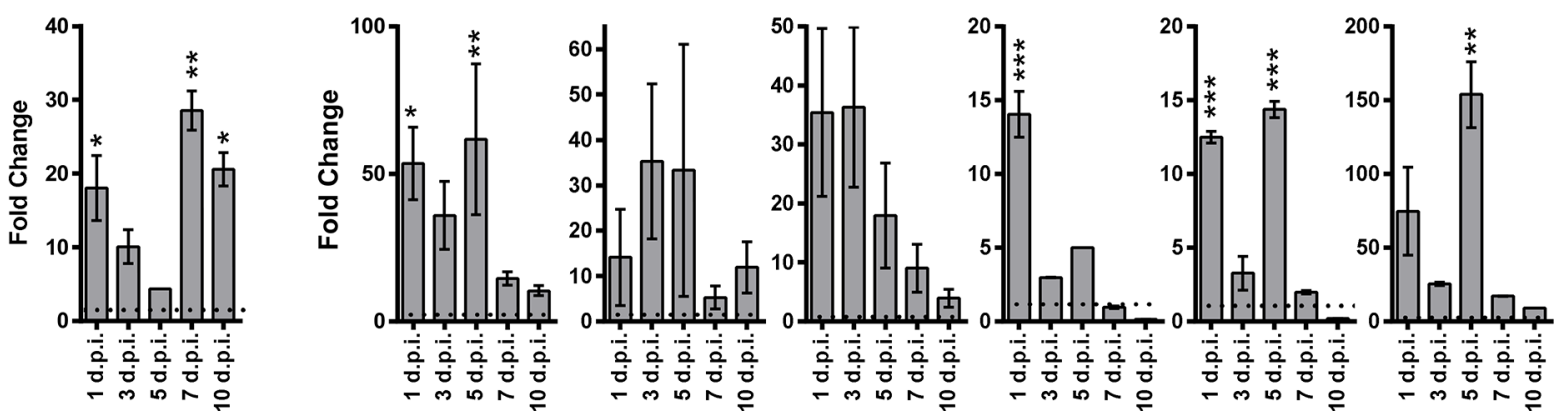

Figure 7. Late-stage reovirus-driven $\mathrm{CD} 11 \mathrm{~b}^{+}, \mathrm{Ly}_{6} \mathrm{G}^{-}, \mathrm{Ly}_{6 \mathrm{C}} \mathrm{C}^{+}$cells acquire $\mathrm{M} 2$-like macrophage characteristics. (A, B) Individual protein profiles of M2- and M1-macrophage-associated proteins, respectively, from total proteomic data set shown in Figure 1B. Flow cytometry analysis of CD206 (C) and CCR2 (D) surface expression on CD11b $\mathrm{b}^{+}, \mathrm{Ly}_{6 \mathrm{G}}{ }^{-}, \mathrm{Ly} 6 \mathrm{C}^{\text {high-low }}$ cells. qRT-PCR analysis of isolated CD11 $\mathrm{b}^{+}, \mathrm{Ly} 6 \mathrm{G}^{-}, \mathrm{Ly} 6 \mathrm{C}^{\text {high-low }}$ cells for Irf4 (E), Irf5 (F), Ccl17 (G), and M1-macrophage-associated genes (H). Flow cytometry analysis for CD206 (C) and CCR2 (D) represents mean \pm SEM with $n=3-5$ mice. qRT-PCR analysis in (E, F) are from a pooled population of 5-10 mice, $n=2$, ran in duplicate, normalized to GAPDH, and compared to 1 d.p.i. BM sample (indicated by the dotted line) to obtain the fold change. One-way ANOVA with Bonferroni post-test (C-H) with $95 \%$ confidence interval was used for statistical analysis, and $p$-values of $<0.05$ were considered significant. Asterisks were used to signify $p$-values as $* p \leq 0.05$, $* * p \leq 0.01$, and $* * * p \leq 0.001$.

tion (Figure S-6D), and proton leak (Figure S-6E) at 7 d.p.i., suggesting higher bioenergetic demand at 7 d.p.i.. Concurrently, basal extracellular acidification rate (ECAR) (Figure 6E and Figure S-6F) of isolated $\mathrm{CD} 11 \mathrm{~b}^{+}, \mathrm{Ly}_{6 \mathrm{G}}{ }^{-}, \mathrm{Ly} 6 \mathrm{C}^{\text {high-low }}$ cells were also greatest at 7-10 d.p.i. Importantly, the opposing trend was observed with spare respiratory capacity (Figure $6 \mathrm{~F}$ ), maximal OCR (Figure S-6G), and glycolytic reserve (Figure 6G and Figure $\mathrm{S}-6 \mathrm{H})$, indicating that these cells utilize glycolysis close to their theoretical maximum at 7-10 d.p.i. These data show that inflammatory $\mathrm{CD}_{11 \mathrm{~b}^{+}}, \mathrm{Ly}_{6 \mathrm{G}}^{-}$, Ly6 $\mathrm{C}^{\text {high-low }}$ cells undergo metabolic reprogramming at the SOI and increase both glycolytic and respiratory capacities during the later stages of infection.
Virus-Driven CD11b+ Ly6G $^{-}$, Ly6C ${ }^{\text {high }}$ Cells Acquire M2-like Macrophage Characteristics

It has been hypothesized that immature myeloid cells give rise to antigen-presenting cells (APCs), especially those of monocytic

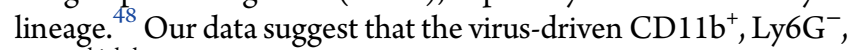
Ly6C $C^{\text {high-low }}$ cells undergo temporal transformation and acquire molecular signatures of APCs. Hence, we next investigated whether these myeloid cells differentiate into any specific subtype of the APCs. The QTiPs data (Figure 7A) identified an increasing trend for proteins (CCL24, ARG-1, Alox15, Stab1, and TGF- $\beta$ ) characteristic of M2 macrophages between 1 and 10 d.p.i. in SOI-isolated myeloid cells. In contrast, M1-macrophage- 
associated proteins (IRF5, MMP9, and IRF1) showed the opposing trend (Figure 7B). In support of this, flow cytometry analysis of inflammatory $\mathrm{CD} 11 \mathrm{~b}^{+}, \mathrm{Ly}_{6} \mathrm{G}^{-}$, Ly6 $\mathrm{C}^{\text {high-low }}$ cells further identified contrasting kinetics for the surface expression of M2 macrophage marker CD206 (increased over time; Figure 7C) and M1 macrophage marker CCR2 (decreased over time; Figure 7D). In line with our metabolic bioenergetics, these results reveal the transition of inflammatory $\mathrm{CD} 11 \mathrm{~b}^{+}, \mathrm{Ly}_{6 \mathrm{G}}$, Ly6C $\mathrm{C}^{\text {high-low }}$ cells into M2-like macrophages around 7-10 d.p.i.

To further strengthen our hypothesis that the inflammatory

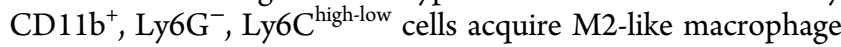
characteristics, we performed qRT-PCR on SOI- and BM-isolated $\mathrm{CD}_{11 b^{+}}, \mathrm{Ly}_{6 \mathrm{G}}{ }^{-}, \mathrm{Ly} 6 \mathrm{C}^{\text {high-low }}$ cells. First, we analyzed the expression of key transcription factors Irf4 and Irf5 known to be involved in M2 vs M1 macrophage polarization, respectively. ${ }^{49-51}$ As shown in Figure 7E and F, SOI-isolated myeloid cells showed contrasting profiles of Irf4 and Irf5 between 1 and 10 d.p.i.; the levels of M2-macrophage transcription factor Irf4 increased over time, whereas Irf5 decreased over time. Furthermore, using a list of M2 and M1 macrophage markers, ${ }^{52,53}$ we showed that M2-associated marker $\mathrm{Ccl} 17$ followed a similar trend as Irf4 (Figure 7G), whereas additional M2-associated genes (Ym1, Cd206, and Il4) displayed mostly nonsignificant changes (Figure S-7A). Importantly, the expression of M1-associated markers (Cd86, Il-1 $\beta, C d 68$, Socs1, Tnf $\alpha$, and Ifn $\gamma$ ) showed an opposing trend throughout infection with decreasing expression from 1 to 10 d.p.i. (Figure $7 \mathrm{H}$ ). Analysis of M2- and M1-associated genes in the BM-isolated cells showed little significant variation (Figure S-7B and C, respectively). These results, in combination with QTiPs analysis, conclusively demonstrate that the virus-driven $\mathrm{CD} 11 \mathrm{~b}^{+}, \mathrm{Ly} 6 \mathrm{G}^{-}, \mathrm{Ly} 6 \mathrm{C}^{\text {high-low }}$ cells undergo phenotypic and functional transition at the SOI and acquire the characteristics of M2 macrophages.

\section{DISCUSSION}

Myeloid cells and their descendants, including monocytes, dendritic cells, macrophages, or myeloid-derived suppressor cells (MDSCs), play pivotal roles in both innate and adaptive immunity during infections. With regard to viral infections, newly recruited Ly6 $\mathrm{C}^{\text {high }}$ monocytes have been implicated in viral clearance following infection with West Nile virus, vaccinia virus, murine cytomegalovirus, and influenza virus. ${ }^{54-56}$ These studies demonstrate that viral-driven myeloid cells readily interact with other innate (NK cells) and adaptive cells (virus-specific CD8+ $\mathrm{T}$ cells $)^{11,56}$ and contribute toward viral clearance as well as disease pathology through direct or indirect mechanisms. For instance, inflammatory myeloid cells recruited following mouse hepatitis virus (MHV) contribute toward virus clearance through a CCR2-dependent mechanism. ${ }^{57}$ Furthermore, influenza-mediated $\mathrm{CD} 11 \mathrm{~b}^{+}, \mathrm{Ly} 6 \mathrm{C}^{\text {high }}$ cell recruitment is a major contributor to excessive collateral damage within the lungs, and the absence of such recruitment compromises viral clearance and decreases the $\mathrm{CD} 8+\mathrm{T}$ cell frequency. ${ }^{11}$ In congruence with these reports, our data demonstrates that the recruitment of reovirus-driven $\mathrm{CD}_{11 \mathrm{~b}^{+}, \mathrm{Ly} 6 \mathrm{G}^{-} \text {, Ly6C }}{ }^{\text {high }}$ inflammatory cells is CCR2-dependent (Figure 4D) and that their presence at the SOI positively correlates with viral clearance (Figure 4E). Interestingly, at the SOI, intracellular virus be found within the cells with and without the CD $11 b^{+}$, Ly $_{6} \mathrm{G}^{-}$, Ly6 $\mathrm{C}^{\text {high }}$ phenotype (Figure 4E), suggesting the involvement of other immune cells in antiviral immune reactivities. Thus, it could be concluded that virus-driven $\mathrm{CD}_{11} \mathrm{~b}^{+}$, Ly $6 \mathrm{G}^{-}$, Ly6C $\mathrm{C}^{\text {high }}$ inflammatory cells, in combination with other immune constituents, contribute toward virus clearance.
Here, we provide the first comprehensive temporospatial quantitative proteomic analysis of inflammatory CD $11 \mathrm{~b}^{+}, \mathrm{Ly} 6 \mathrm{G}^{-}$, Ly6C ${ }^{\text {high-low }}$ cells directly isolated from their in situ microenvironment. Notably, our QTiPs approach accounts for host environmental factors, such as cytokines, metabolic changes, and immune infiltrating/resident cells, at the SOI. In combination with detailed biological validation, the QTiPs data show that reovirusdriven $\mathrm{CD} 11 \mathrm{~b}^{+}, \mathrm{Ly}_{6 \mathrm{G}} \mathrm{G}^{-}$, Ly6 $\mathrm{C}^{\text {high-low }}$ cells have differential roles throughout the course of infection: newly recruited $\mathrm{CD} 11 \mathrm{~b}^{+}$, Ly6G ${ }^{-}$, Ly6 $\mathrm{C}^{\text {high }}$ cells mount a robust immune response and aid in viral clearance during the early phase of infection ( $1-5$ d.p.i.), whereas during late phase infection (7 and 10 d.p.i.), these cells undergo a metabolic shift, acquire enhanced antigen-presentation capacity, and achieve M2-like macrophage characteristics.

Quantitative multiplexed proteomic approaches (e.g., labelfree, tags, or stable isotope labeling) represent an unbiased strategy to observe global proteomic changes and answer key biological questions. With respect to immunological studies, label-free quantitation has been the predominant means to investigate proteomic discrepancies of ex vivo expanded/ cultured or transformed cell lines (e.g., cytotoxic $\mathrm{T}$ lymphocytes, ${ }^{58}$ dendritic cells, and/or macrophages ${ }^{59-61}$ ), and primaryisolated cells such as dendritic cell subsets, ${ }^{62}$ MDSCs, ${ }^{63}$ and human $\mathrm{T}$ cells. ${ }^{64}$ Unlike such label-free approaches, TMT reagents now facilitate simultaneous analysis of 10 proteomes. Employing TMT in our QTiPs approach enabled accurate and deep proteomic coverage of in vivo proteomic profiles of isolated $\mathrm{CD}_{11} \mathrm{~b}^{+}, \mathrm{Ly}_{6 \mathrm{G}}{ }^{-}, \mathrm{Ly} 6 \mathrm{C}^{\text {high-low }}$ cells. The temporal nature of the data set revealed a secondary phase of antiviral/wound damage response at 5 d.p.i. indicative of increased type I and II IFNassociated proteins (e.g., IFI5A, IRF5, IRG1, and Q9DCE9, an IFN- $\gamma$-induced GTPase). IFI5A in particular has been shown to be a transcriptional regulatory factor induced during myeloid cell development ${ }^{65}$ and may have implications in $\mathrm{CD} 11 \mathrm{~b}^{+}$, Ly6G ${ }^{-}$, Ly6 $C^{\text {high-low }}$ cell differentiation at 5-10 d.p.i. Furthermore, late stage variations illustrated in clusters \#4 and 5 or Mito-clusters \#1 and 2 correlate with increased antigen presentation/processing and metabolic shift, respectively. Such temporal fluctuations in the proteomes highlight the advantages of utilizing an approach that monitors the in vivo dynamics of an immune cell population. Our QTiPs approach provides a global, timely, and in depth platform facilitating the capture of immune cell transitions while accounting for the interplay between cytokines and immune cells throughout the course of infection.

Considering the current contentious nomenclature and phenotypic categorization around myeloid cells and its derivative subpopulations, ${ }^{52}$ we identified virus-driven murine myeloid cells simply by their factual phenotype (based on CD11b, Ly6G, and Ly6C surface expression). To this end, we viewed these myeloid cells as a newly recruited cell population at the SOI and then analyzed their transition into existing paradigmal subpopulations in terms of surface marker, gene expression, protein, and metabolic profiles. Our temporal analysis reveals that SOI-associated $\mathrm{CD} 11 \mathrm{~b}^{+}, \mathrm{Ly}_{6 \mathrm{G}}{ }^{-}, \mathrm{Ly} 6 \mathrm{C}^{\text {high }}$ cells undergo a time-dependent decrease in Ly6C expression and display increased MHC-II expression and wound healing characteristics at 7-10 d.p.i., suggesting maturation/differentiation during the later stages of infection. Upon further dissection, we observed that M2-macrophage-associated proteins and transcripts increase at 7-10 d.p.i. as opposed to pro-inflammatory/M1-macrophageassociated markers that are upregulated during the early stages of infection. Similar to myeloid cells, there is a growing appreciation for the plasticity of the distinction between M1- vs M2-like 
macrophages. It is now acknowledged that macrophages rather demonstrate a spectrum of phenotypic, functional, and physiological features of M1 and M2 classes and thus often display these features in a context-dependent manner. It should be noted that many of the M1- or M2-associated features have been originally discovered in the context of the macrophages that were generated using defined in vitro growth conditions, such as through the supplementation of GM-CSF or M-CSF. Thus, it is possible that cells differentiated in the context of the complex in vivo milieu hosting a myriad of soluble and cellular interacting partners bear a differential pattern of M1 and M2 markers that is observed with the in vitro-generated macrophages. In our analysis, virus-driven $\mathrm{CD}_{11 \mathrm{~b}^{+}}, \mathrm{Ly}_{6 \mathrm{G}}$, , Ly6 $\mathrm{C}^{\text {high }}$ cells show several M2-associated markers during the later phases of infection; however, at the same, these cells failed to show any congruent trends with of I14, Ym1, and Cd206 gene expression that have been described to be associated with the M2 phenotype. On the basis of these findings, we surmise that the macrophages generated in a complex in vivo microenvironment differ from those generated in vitro using defined growth conditions and should be considered as such with a special consideration for their microenvironmental context.

The metabolic signature of myeloid cells, particularly macrophages, is a major hallmark to distinguish contrasting M1 vs M2 macrophage phenotypes. ${ }^{66}$ In comparison to this existing paradigm and our own experiments with ex vivo-generated/cultured M1- and M2-like macrophages (Figure S-7D, E), ${ }^{66}$ we observed

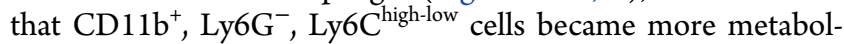
ically active during the later stages of infection, as indicated by increasing basal OCR and basal ECAR (Figure 6D, E). Such a metabolic shift could be indicative of the necessity to require energy for newly acquired endocytic, antigen presentation, and/ or M2-like functionality. In the context of currently reported metabolic profiles assigned to M1- (low basal OCR, high basal ECAR, and low spare respiratory capacity) and M2- (high OCR, low basal ECAR, and high spare respiratory capacity) macrophages, the infection-driven $\mathrm{CD}_{11 \mathrm{~b}^{+}}, \mathrm{Ly}_{6 \mathrm{G}}$,, $\mathrm{Ly} 6 \mathrm{C}^{\text {high-low }}$ cells demonstrate a dynamic metabolic signature in the transition between M1- and M2-like macrophages in line with the proteomic signature elucidated through QTiPs. This analysis further confirms the highly plastic nature of the myeloid cellmacrophage transition and, in line with the recent evidence ${ }^{67,68}$ specifically using lipopolysaccharide/TLR4 stimulation versus IL-4-stimulated BM-derived macrophages, further supports the hypothesis that in vitro-generated macrophages do not completely recapitulate all metabolic and functional characteristics of in vivo-isolated or human cells.

In conclusion, QTiPs analysis comprehensively captures the temporospatial transition of inflammatory $\mathrm{CD} 11 \mathrm{~b}^{+}, \mathrm{Ly}_{6 \mathrm{G}}{ }^{-}$, Ly6C $\mathrm{C}^{\text {high-low }}$ cells following reovirus infection. These data contain a plethora of information on native, as well as infection-driven, myeloid cells that reside in the BM or at the SOI and are a resource for future hypothesis testing with regard to myeloidspecific differentiation, antiviral response, and metabolic alteration. The data also have implications for the therapeutic management of myeloid cells in the context of antiviral immune responses, vaccine development, cancer immunotherapies, and especially oncolytic virus therapies, which are known to drive myeloid cell recruitment to the tumor microenvironment following administration. ${ }^{26}$ Our data also demonstrate that the QTiPs approach can be applied further to precisely capture the complex, dynamic, and temporal nature of other types of immune cells collected from their in situ microenvironment.

\section{ASSOCIATED CONTENT}

\section{Supporting Information}

The Supporting Information is available free of charge on the ACS Publications website at DOI: 10.1021/acs.jproteome.7b00425.

Figure S-1, Ly6C surface expression loss throughout the course of infection and GO annotation analysis; Figure S-2, heatmap representation for clusters $\# 1-3$ and 6-10; Figure S-3, frequency/kinetic analysis of WT vs CCR2KO mice for CD $11 b^{+}, \mathrm{Ly}_{6 \mathrm{G}^{-}}$, Ly6 $\mathrm{C}^{\text {high-low }}$ cells and qRT-PCR gene specific validation for clusters \#1-3; Figure S-4, cluster \#5 analysis of mitochondrion-associated proteins from the total CD $11 b^{+}, \mathrm{Ly}_{6 \mathrm{G}^{-}}, \mathrm{Ly} 6 \mathrm{C}^{\text {high-low }}$ cell proteomic data set; Figure S-5, additional Mito-cluster \#3-10 from mitochondrial localized proteins; Figure S-6, assessment of the $\mathrm{CD}_{11 \mathrm{~b}^{+}}$, Ly $6 \mathrm{G}^{-}$, Ly6C $\mathrm{C}^{\text {high-low }}$ myeloid cells' metabolic activity; Figure S-7, M1- vs M2-like macrophage phenotyping; Data $S-1$, total proteome data set of isolated $\mathrm{CD}_{11 b^{+}, \mathrm{Ly}_{6} \mathrm{G}^{-}, \text {Ly6C }} \mathrm{Cigh}^{\text {how }}$ myeloid cells (PDF)

Relative intensities of genes at various $\mathrm{PC}$ and $\mathrm{BM}$ d.p.i. (XLSX)

\section{AUTHOR INFORMATION}

\section{Corresponding Author}

*E-mail: shashi.gujar@dal.ca. ORCID (1)

Shashi Gujar: 0000-0002-5427-0829

\section{Author Contributions}

D.R.C., J.P.M., A.S., B.E.K., Y.K., and S.G. conceived the approach and performed experiments. J.A.P. helped with sample preparation and processing. D.R.C. and J.P.M. performed the data analysis. E.H., S.A., N.H., P.K., T.S., M.P.W., S.P.G., and P.W.L. provided input. D.R.C., J.P.M., and S.G. wrote the manuscript.

Notes

The authors declare no competing financial interest.

\section{ACKNOWLEDGMENTS}

This work was supported by grants from the Canadian Institutes of Health Research (CIHR) and Terry Fox Research Institute (TFRI) to S.G. and P.W.L. Authors D.R.C., Y.K., and T.S. are supported by the CIHR. J.P.M. and B.E.K. are supported through the Cancer Research Training Program (CRTP) of BHCRI. D.R.C. was supported previously by CRTP from BHCRI and the Nova Scotia Health Research Foundation (NSHRF). Nova Scotia Graduate Scholarships fund both N.H. and P.K. Work by J.A.P. was funded in part by NIH/NIDDK grant K01 DK098285. M.P.W. was supported by a Wellcome Trust Senior Fellowship (108070/Z/15/Z). We acknowledge Devanand Pinto and Ken Chisholm (National Research Council) as well as Alejandro Cohen at the Dalhousie Proteomics Core Facility and Derek Rowter and Renee Raudonis at Dalhousie Flow cytometry suites.

\section{REFERENCES}

(1) Xiong, H.; Keith, J. W.; Samilo, D. W.; Carter, R. A.; Leiner, I. M.; Pamer, E. G. Innate Lymphocyte/Ly6C(hi) Monocyte Crosstalk Promotes Klebsiella Pneumoniae Clearance. Cell 2016, 165, 679-689.

(2) Serbina, N. V.; Pamer, E. G. Monocyte emigration from bone marrow during bacterial infection requires signals mediated by chemokine receptor CCR2. Nat. Immunol. 2006, 7, 311-317. 
(3) Verollet, C.; Souriant, S.; Bonnaud, E.; Jolicoeur, P.; RaynaudMessina, B.; Kinnaer, C.; Fourquaux, I.; Imle, A.; Benichou, S.; Fackler, O. T.; Poincloux, R.; Maridonneau-Parini, I. HIV-1 reprograms the migration of macrophages. Blood 2015, 125, 1611-1622.

(4) Whitfield-Larry, F.; Felton, J.; Buse, J.; Su, M. A. Myeloid-derived suppressor cells are increased in frequency but not maximally suppressive in peripheral blood of Type 1 Diabetes Mellitus patients. Clin. Immunol. 2014, 153, 156-164.

(5) Koffel, R.; Meshcheryakova, A.; Warszawska, J.; Hennig, A.; Wagner, K.; Jorgl, A.; Gubi, D.; Moser, D.; Hladik, A.; Hoffmann, U.; Fischer, M. B.; van den Berg, W.; Koenders, M.; Scheinecker, C.; Gesslbauer, B.; Knapp, S.; Strobl, H. Monocytic cell differentiation from band-stage neutrophils under inflammatory conditions via MKK6 activation. Blood 2014, 124, 2713-2724.

(6) Kumar, V.; Cheng, P.; Condamine, T.; Mony, S.; Languino, L. R.; McCaffrey, J. C.; Hockstein, N.; Guarino, M.; Masters, G.; Penman, E.; Denstman, F.; Xu, X.; Altieri, D. C.; Du, H.; Yan, C.; Gabrilovich, D. I. CD45 Phosphatase Inhibits STAT3 Transcription Factor Activity in Myeloid Cells and Promotes Tumor-Associated Macrophage Differentiation. Immunity 2016, 44, 303-315.

(7) Kumar, V.; Patel, S.; Tcyganov, E.; Gabrilovich, D. I. The Nature of Myeloid-Derived Suppressor Cells in the Tumor Microenvironment. Trends Immunol. 2016, 37, 208-220.

(8) Azzaoui, I.; Uhel, F.; Rossille, D.; Pangault, C.; Dulong, J.; Le Priol, J.; Lamy, T.; Houot, R.; Le Gouill, S.; Cartron, G.; Godmer, P.; Bouabdallah, K.; Milpied, N.; Damaj, G.; Tarte, K.; Fest, T.; Roussel, M. $\mathrm{T}$-cell defect in diffuse large B-cell lymphomas involves expansion of myeloid-derived suppressor cells. Blood 2016, 128, 1081-1092.

(9) Zirlik, K. MDSCs: the final frontier of the microenvironment in CLL? Blood 2014, 124, 666-668.

(10) Kloepper, J.; Riedemann, L.; Amoozgar, Z.; Seano, G.; Susek, K.; Yu, V.; Dalvie, N.; Amelung, R. L.; Datta, M.; Song, J. W.; Askoxylakis, V.; Taylor, J. W.; Lu-Emerson, C.; Batista, A.; Kirkpatrick, N. D.; Jung, K.; Snuderl, M.; Muzikansky, A.; Stubenrauch, K. G.; Krieter, O.; Wakimoto, H.; Xu, L.; Munn, L. L.; Duda, D. G.; Fukumura, D.; Batchelor, T. T.; Jain, R. K. Ang-2/VEGF bispecific antibody reprograms macrophages and resident microglia to anti-tumor phenotype and prolongs glioblastoma survival. Proc. Natl. Acad. Sci. U. S. A. 2016, 113, 4476-4481.

(11) Aldridge, J. R., Jr; Moseley, C. E.; Boltz, D. A.; Negovetich, N. J.; Reynolds, C.; Franks, J.; Brown, S. A.; Doherty, P. C.; Webster, R. G.; Thomas, P. G. TNF/iNOS-producing dendritic cells are the necessary evil of lethal influenza virus infection. Proc. Natl. Acad. Sci. U. S. A. 2009, 106, 5306-5311.

(12) Peters, W.; Dupuis, M.; Charo, I. F. A mechanism for the impaired IFN-gamma production in C-C chemokine receptor 2 (CCR2) knockout mice: role of CCR2 in linking the innate and adaptive immune responses. J. Immunol. 2000, 165, 7072-7077.

(13) McAlister, G. C.; Huttlin, E. L.; Haas, W.; Ting, L.; Jedrychowski, M. P.; Rogers, J. C.; Kuhn, K.; Pike, I.; Grothe, R. A.; Blethrow, J. D.; Gygi, S. P. Increasing the multiplexing capacity of TMTs using reporter ion isotopologues with isobaric masses. Anal. Chem. 2012, 84, 74697478.

(14) Weekes, M. P.; Tomasec, P.; Huttlin, E. L.; Fielding, C. A.; Nusinow, D.; Stanton, R. J.; Wang, E. C.; Aicheler, R.; Murrell, I.; Wilkinson, G. W.; Lehner, P. J.; Gygi, S. P. Quantitative temporal viromics: an approach to investigate host-pathogen interaction. Cell 2014, 157, 1460-1472.

(15) Ting, L.; Rad, R.; Gygi, S. P.; Haas, W. MS3 eliminates ratio distortion in isobaric multiplexed quantitative proteomics. Nat. Methods 2011, 8, 937-940.

(16) McAlister, G. C.; Nusinow, D. P.; Jedrychowski, M. P.; Wuhr, M.; Huttlin, E. L.; Erickson, B. K.; Rad, R.; Haas, W.; Gygi, S. P. MultiNotch MS3 enables accurate, sensitive, and multiplexed detection of differential expression across cancer cell line proteomes. Anal. Chem. 2014, 86, 7150-7158.

(17) Bouziat, R.; Hinterleitner, R.; Brown, J. J.; Stencel-Baerenwald, J. E.; Ikizler, M.; Mayassi, T.; Meisel, M.; Kim, S. M.; Discepolo, V.; Pruijssers, A. J.; Ernest, J. D.; Iskarpatyoti, J. A.; Costes, L. M.; Lawrence,
I.; Palanski, B. A.; Varma, M.; Zurenski, M. A.; Khomandiak, S.; McAllister, N.; Aravamudhan, P.; Boehme, K. W.; Hu, F.; Samsom, J. N.; Reinecker, H. C.; Kupfer, S. S.; Guandalini, S.; Semrad, C. E.; Abadie, V.; Khosla, C.; Barreiro, L. B.; Xavier, R. J.; Ng, A.; Dermody, T. S.; Jabri, B. Reovirus infection triggers inflammatory responses to dietary antigens and development of celiac disease. Science 2017, 356, 44-50.

(18) Hata, Y.; Etoh, T.; Inomata, M.; Shiraishi, N.; Nishizono, A.; Kitano, S. Efficacy of oncolytic reovirus against human breast cancer cells. Oncol. Rep. 2008, 19, 1395-1398.

(19) Norman, K. L.; Coffey, M. C.; Hirasawa, K.; Demetrick, D. J.; Nishikawa, S. G.; DiFrancesco, L. M.; Strong, J. E.; Lee, P. W. Reovirus oncolysis of human breast cancer. Hum. Gene Ther. 2002, 13, 641-652.

(20) Clements, D.; Helson, E.; Gujar, S. A.; Lee, P. W. K. Reovirus in cancer therapy: an evidence-based review. Oncolytic Virother. 2014, 3, $69-82$.

(21) Yang, W. Q.; Lun, X.; Palmer, C. A.; Wilcox, M. E.; Muzik, H.; Shi, Z. Q.; Dyck, R.; Coffey, M.; Thompson, B.; Hamilton, M.; Nishikawa, S. G.; Brasher, P. M.; Fonseca, K.; George, D.; Rewcastle, N. B.; Johnston, R. N.; Stewart, D.; Lee, P. W.; Senger, D. L.; Forsyth, P. A. Efficacy and safety evaluation of human reovirus type 3 in immunocompetent animals: racine and nonhuman primates. Clin. Cancer Res. 2004, 10, $8561-8576$.

(22) Pandha, H. S.; Heinemann, L.; Simpson, G. R.; Melcher, A.; Prestwich, R.; Errington, F.; Coffey, M.; Harrington, K. J.; Morgan, R. Synergistic effects of oncolytic reovirus and cisplatin chemotherapy in murine malignant melanoma. Clin. Cancer Res. 2009, 15, 6158-6166.

(23) Sei, S.; Mussio, J. K.; Yang, Q. E.; Nagashima, K.; Parchment, R. E.; Coffey, M. C.; Shoemaker, R. H.; Tomaszewski, J. E. Synergistic antitumor activity of oncolytic reovirus and chemotherapeutic agents in non-small cell lung cancer cells. Mol. Cancer 2009, 8, 47-4598-8-47.

(24) Gujar, S. A.; Lee, P. W. Oncolytic virus-mediated reversal of impaired tumor antigen presentation. Front. Oncol. 2014, 4, 77.

(25) Clements, D. R.; Kim, Y.; Gujar, S. A.; Lee, P. W. All that glitters is not gold: the need to consider desirable and undesirable immune aspects of oncolytic virus therapy. Oncoimmunology 2016, 5, e1057674.

(26) Clements, D. R.; Sterea, A. M.; Kim, Y.; Helson, E.; Dean, C. A.; Nunokawa, A.; Coyle, K. M.; Sharif, T.; Marcato, P.; Gujar, S. A.; Lee, P. W. Newly Recruited CD11b+, GR-1+, Ly6Chigh Myeloid Cells Augment Tumor-Associated Immunosuppression Immediately following the Therapeutic Administration of Oncolytic Reovirus. J. Immunol. 2015, 194, 4397-4412.

(27) Gujar, S. A.; Clements, D.; Dielschneider, R.; Helson, E.; Marcato, P.; Lee, P. W. Gemcitabine enhances the efficacy of reovirus-based oncotherapy through anti-tumour immunological mechanisms. Br. J. Cancer 2014, 110, 83-93.

(28) Murphy, J. P.; Stepanova, E.; Everley, R. A.; Paulo, J. A.; Gygi, S. P. Comprehensive Temporal Protein Dynamics during the Diauxic Shift in Saccharomyces cerevisiae. Mol. Cell. Proteomics 2015, 14, 2454-2465.

(29) Rappsilber, J.; Ishihama, Y.; Mann, M. Stop and go extraction tips for matrix-assisted laser desorption/ionization, nanoelectrospray, and LC/MS sample pretreatment in proteomics. Anal. Chem. 2003, 75, 663-670.

(30) Ashburner, M.; Ball, C. A.; Blake, J. A.; Botstein, D.; Butler, H.; Cherry, J. M.; Davis, A. P.; Dolinski, K.; Dwight, S. S.; Eppig, J. T.; Harris, M. A.; Hill, D. P.; Issel-Tarver, L.; Kasarskis, A.; Lewis, S.; Matese, J. C.; Richardson, J. E.; Ringwald, M.; Rubin, G. M.; Sherlock, G. Gene ontology: tool for the unification of biology. The Gene Ontology Consortium. Nat. Genet. 2000, 25, 25-29.

(31) Gene Ontology Consortium. Gene Ontology Consortium: going forward. Nucleic Acids Res. 2015, 43, D1049-56.

(32) Saeed, A. I.; Sharov, V.; White, J.; Li, J.; Liang, W.; Bhagabati, N.; Braisted, J.; Klapa, M.; Currier, T.; Thiagarajan, M.; Sturn, A.; Snuffin, M.; Rezantsev, A.; Popov, D.; Ryltsov, A.; Kostukovich, E.; Borisovsky, I.; Liu, Z.; Vinsavich, A.; Trush, V.; Quackenbush, J. TM4: a free, opensource system for microarray data management and analysis. BioTechniques 2003, 34, 374-378.

(33) Rusinova, I.; Forster, S.; Yu, S.; Kannan, A.; Masse, M.; Cumming, H.; Chapman, R.; Hertzog, P. J. Interferome v2.0: an updated database 
of annotated interferon-regulated genes. Nucleic Acids Res. 2013, 41, D1040-6.

(34) Calvo, S. E.; Clauser, K. R.; Mootha, V. K. MitoCarta2.0: an updated inventory of mammalian mitochondrial proteins. Nucleic Acids Res. 2016, 44, D1251-7.

(35) Pagliarini, D. J.; Calvo, S. E.; Chang, B.; Sheth, S. A.; Vafai, S. B.; Ong, S. E.; Walford, G. A.; Sugiana, C.; Boneh, A.; Chen, W. K.; Hill, D. E.; Vidal, M.; Evans, J. G.; Thorburn, D. R.; Carr, S. A.; Mootha, V. K. A mitochondrial protein compendium elucidates complex I disease biology. Cell 2008, 134, 112-123.

(36) Vizcaino, J. A.; Deutsch, E. W.; Wang, R.; Csordas, A.; Reisinger, F.; Rios, D.; Dianes, J. A.; Sun, Z.; Farrah, T.; Bandeira, N.; Binz, P. A.; Xenarios, I.; Eisenacher, M.; Mayer, G.; Gatto, L.; Campos, A.; Chalkley, R. J.; Kraus, H. J.; Albar, J. P.; Martinez-Bartolome, S.; Apweiler, R; Omenn, G. S.; Martens, L.; Jones, A. R.; Hermjakob, H. ProteomeXchange provides globally coordinated proteomics data submission and dissemination. Nat. Biotechnol. 2014, 32, 223-226.

(37) Vizcaino, J. A.; Csordas, A.; del-Toro, N.; Dianes, J. A.; Griss, J.; Lavidas, I.; Mayer, G.; Perez-Riverol, Y.; Reisinger, F.; Ternent, T.; Xu, Q. W.; Wang, R.; Hermjakob, H. 2016 update of the PRIDE database and its related tools. Nucleic Acids Res. 2016, 44, D447-56.

(38) Coffey, M. C.; Strong, J. E.; Forsyth, P. A.; Lee, P. W. Reovirus therapy of tumors with activated Ras pathway. Science 1998, 282, 13321334.

(39) Marcato, P.; Shmulevitz, M.; Pan, D.; Stoltz, D.; Lee, P. W. Ras transformation mediates reovirus oncolysis by enhancing virus uncoating, particle infectivity, and apoptosis-dependent release. Mol. Ther. 2007, 15, 1522-1530.

(40) Livak, K. J.; Schmittgen, T. D. Analysis of relative gene expression data using real-time quantitative PCR and the 2(-Delta Delta C (T)) Method. Methods 2001, 25, 402-408.

(41) Huang; da, W.; Sherman, B. T.; Lempicki, R. A. Bioinformatics enrichment tools: paths toward the comprehensive functional analysis of large gene lists. Nucleic Acids Res. 2009, 37, 1-13.

(42) Huang; da, W.; Sherman, B. T.; Lempicki, R. A. Systematic and integrative analysis of large gene lists using DAVID bioinformatics resources. Nat. Protoc. 2009, 4, 44-57.

(43) Roy, D.; Bell, J. Cell carriers for oncolytic viruses; current challenges and future directions. Oncolytic Virother. 2013, 2013 (2), 4756.

(44) Peng, K. W.; Dogan, A.; Vrana, J.; Liu, C.; Ong, H. T.; Kumar, S.; Dispenzieri, A.; Dietz, A. B.; Russell, S. J. Tumor-associated macrophages infiltrate plasmacytomas and can serve as cell carriers for oncolytic measles virotherapy of disseminated myeloma. Am. J. Hematol. 2009, 84, 401-407.

(45) Muthana, M.; Rodrigues, S.; Chen, Y. Y.; Welford, A.; Hughes, R.; Tazzyman, S.; Essand, M.; Morrow, F.; Lewis, C. E. Macrophage delivery of an oncolytic virus abolishes tumor regrowth and metastasis after chemotherapy or irradiation. Cancer Res. 2013, 73, 490-495.

(46) Zhang, T.; Maekawa, Y.; Hanba, J.; Dainichi, T.; Nashed, B. F.; Hisaeda, H.; Sakai, T.; Asao, T.; Himeno, K.; Good, R. A.; Katunuma, N. Lysosomal cathepsin B plays an important role in antigen processing, while cathepsin $\mathrm{D}$ is involved in degradation of the invariant chain inovalbumin-immunized mice. Immunology 2000, 100, 13-20.

(47) Szklarczyk, D.; Franceschini, A.; Wyder, S.; Forslund, K.; Heller, D.; Huerta-Cepas, J.; Simonovic, M.; Roth, A.; Santos, A.; Tsafou, K. P.; Kuhn, M.; Bork, P.; Jensen, L. J.; von Mering, C. STRING v10: proteinprotein interaction networks, integrated over the tree of life. Nucleic Acids Res. 2015, 43, D447-52.

(48) Zigmond, E.; Varol, C.; Farache, J.; Elmaliah, E.; Satpathy, A. T.; Friedlander, G.; Mack, M.; Shpigel, N.; Boneca, I. G.; Murphy, K. M.; Shakhar, G.; Halpern, Z.; Jung, S. Ly6C hi monocytes in the inflamed colon give rise to proinflammatory effector cells and migratory antigenpresenting cells. Immunity 2012, 37, 1076-1090.

(49) Satoh, T.; Takeuchi, O.; Vandenbon, A.; Yasuda, K.; Tanaka, Y.; Kumagai, Y.; Miyake, T.; Matsushita, K.; Okazaki, T.; Saitoh, T.; Honma, K.; Matsuyama, T.; Yui, K.; Tsujimura, T.; Standley, D. M.; Nakanishi, K.; Nakai, K.; Akira, S. The Jmjd3-Irf4 axis regulates M2 macrophage polarization and host responses against helminth infection. Nat. Immunol. 2010, 11, 936-944.

(50) Krausgruber, T.; Blazek, K.; Smallie, T.; Alzabin, S.; Lockstone, H.; Sahgal, N.; Hussell, T.; Feldmann, M.; Udalova, I. A. IRF5 promotes inflammatory macrophage polarization and TH1-TH17 responses. Nat. Immunol. 2011, 12, 231-238.

(51) Weiss, M.; Blazek, K.; Byrne, A. J.; Perocheau, D. P.; Udalova, I. A. IRF5 is a specific marker of inflammatory macrophages in vivo. Mediators Inflammation 2013, 2013, 245804.

(52) Murray, P. J.; Allen, J. E.; Biswas, S. K.; Fisher, E. A.; Gilroy, D. W.; Goerdt, S.; Gordon, S.; Hamilton, J. A.; Ivashkiv, L. B.; Lawrence, T.; Locati, M.; Mantovani, A.; Martinez, F. O.; Mege, J. L.; Mosser, D. M.; Natoli, G.; Saeij, J. P.; Schultze, J. L.; Shirey, K. A.; Sica, A.; Suttles, J.; Udalova, I.; van Ginderachter, J. A.; Vogel, S. N.; Wynn, T. A. Macrophage activation and polarization: nomenclature and experimental guidelines. Immunity 2014, 41, 14-20.

(53) Kobayashi, K.; Imagama, S.; Ohgomori, T.; Hirano, K.; Uchimura, K.; Sakamoto, K.; Hirakawa, A.; Takeuchi, H.; Suzumura, A.; Ishiguro, N.; Kadomatsu, K. Minocycline selectively inhibits M1 polarization of microglia. Cell Death Dis. 2013, 4, e525.

(54) Barbalat, R.; Lau, L.; Locksley, R. M.; Barton, G. M. Toll-like receptor 2 on inflammatory monocytes induces type $I$ interferon in response to viral but not bacterial ligands. Nat. Immunol. 2009, 10, $1200-1207$

(55) Lim, J. K.; Obara, C. J.; Rivollier, A.; Pletnev, A. G.; Kelsall, B. L.; Murphy, P. M. Chemokine receptor Ccr2 is critical for monocyte accumulation and survival in West Nile virus encephalitis. J. Immunol. 2011, 186, 471-478.

(56) Salazar-Mather, T. P.; Orange, J. S.; Biron, C. A. Early murine cytomegalovirus (MCMV) infection induces liver natural killer (NK) cell inflammation and protection through macrophage inflammatory protein 1alpha (MIP-1alpha)-dependent pathways. J. Exp. Med. 1998, $187,1-14$.

(57) Held, K. S.; Chen, B. P.; Kuziel, W. A.; Rollins, B. J.; Lane, T. E. Differential roles of CCL2 and CCR2 in host defense to coronavirus infection. Virology 2004, 329, 251-260.

(58) Hukelmann, J. L.; Anderson, K. E.; Sinclair, L. V.; Grzes, K. M.; Murillo, A. B.; Hawkins, P. T.; Stephens, L. R.; Lamond, A. I.; Cantrell, D. A. The cytotoxic $T$ cell proteome and its shaping by the kinase mTOR. Nat. Immunol. 2016, 17, 104-112.

(59) Na, Y. R.; Hong, J. H.; Lee, M. Y.; Jung, J. H.; Jung, D.; Kim, Y. W.; Son, D.; Choi, M.; Kim, K. P.; Seok, S. H., 2nd Proteomic Analysis Reveals Distinct Metabolic Differences Between Granulocyte-Macrophage Colony Stimulating Factor (GM-CSF) and Macrophage Colony Stimulating Factor (M-CSF) Grown Macrophages Derived from Murine Bone Marrow Cells. Mol. Cell. Proteomics 2015, 14, 2722-2732.

(60) Becker, L.; Liu, N. C.; Averill, M. M.; Yuan, W.; Pamir, N.; Peng, Y.; Irwin, A. D.; Fu, X.; Bornfeldt, K. E.; Heinecke, J. W. Unique proteomic signatures distinguish macrophages and dendritic cells. PLoS One 2012, 7, e33297.

(61) Guo, M.; Hartlova, A.; Dill, B. D.; Prescott, A. R.; Gierlinski, M.; Trost, M. High-resolution quantitative proteome analysis reveals substantial differences between phagosomes of RAW 264.7 and bone marrow derived macrophages. Proteomics 2015, 15, 3169-3174.

(62) Luber, C. A.; Cox, J.; Lauterbach, H.; Fancke, B.; Selbach, M.; Tschopp, J.; Akira, S.; Wiegand, M.; Hochrein, H.; O’Keeffe, M.; Mann, M. Quantitative proteomics reveals subset-specific viral recognition in dendritic cells. Immunity 2010, 32, 279-289.

(63) Boutte, A. M.; McDonald, W. H.; Shyr, Y.; Yang, L.; Lin, P. C. Characterization of the MDSC proteome associated with metastatic murine mammary tumors using label-free mass spectrometry and shotgun proteomics. PLoS One 2011, 6, e22446.

(64) Mitchell, C. J.; Getnet, D.; Kim, M. S.; Manda, S. S.; Kumar, P.; Huang, T. C.; Pinto, S. M.; Nirujogi, R. S.; Iwasaki, M.; Shaw, P. G.; Wu, X.; Zhong, J.; Chaerkady, R.; Marimuthu, A.; Muthusamy, B.; Sahasrabuddhe, N. A.; Raju, R.; Bowman, C.; Danilova, L.; Cutler, J.; Kelkar, D. S.; Drake, C. G.; Prasad, T. S.; Marchionni, L.; Murakami, P. N.; Scott, A. F.; Shi, L.; Thierry-Mieg, J.; Thierry-Mieg, D.; Irizarry, R.; Cope, L.; Ishihama, Y.; Wang, C.; Gowda, H.; Pandey, A. A multi-omic 
analysis of human naive CD4+ T cells. BMC Syst. Biol. 2015, 9, 75015-0225-4.

(65) Weiler, S. R.; Gooya, J. M.; Ortiz, M.; Tsai, S.; Collins, S. J.; Keller, J. R. D3: a gene induced during myeloid cell differentiation of Linlo c-Kit + Sca-1(+) progenitor cells. Blood 1999, 93, 527-536.

(66) Tavakoli, S.; Zamora, D.; Ullevig, S.; Asmis, R. Bioenergetic profiles diverge during macrophage polarization: implications for the interpretation of 18F-FDG PET imaging of atherosclerosis. J. Nucl. Med. 2013, 54, 1661-1667.

(67) Lachmandas, E.; Boutens, L.; Ratter, J. M.; Hijmans, A.; Hooiveld, G. J.; Joosten, L. A.; Rodenburg, R. J.; Fransen, J. A.; Houtkooper, R. H.; van Crevel, R.; Netea, M. G.; Stienstra, R. Microbial stimulation of different Toll-like receptor signalling pathways induces diverse metabolic programmes in human monocytes. Nat. Microbiol. 2016, 2, 16246.

(68) Stienstra, R.; Netea-Maier, R. T.; Riksen, N. P.; Joosten, L. A. B.; Netea, M. G. Specific and Complex Reprogramming of Cellular Metabolism in Myeloid Cells during Innate Immune Responses. Cell Metab. 2017, 26, 142-156. 